Article

\title{
Simplified Head-to-Tail Cyclic Polypeptides as Biomaterial-Associated Antimicrobials with Endotoxin Neutralizing and Anti-Inflammatory Capabilities
}

\author{
$\mathrm{Na}$ Dong ${ }^{2}$, Chensi Wang ${ }^{2}$, Xinran $\mathrm{Li}^{2}$, Yuming Guo ${ }^{1, *}$ and Xiaoli $\mathrm{Li}^{3}$ \\ 1 State Key Laboratory of Animal Nutrition, College of Animal Science and Technology, China Agricultural \\ University, Beijing 100193, China \\ 2 The Laboratory of Molecular Nutrition and Immunity, Institute of Animal Nutrition, Northeast Agricultural \\ University, Harbin 150030, China; ndong@neau.edu.cn (N.D.); s1650059155@gmail.com (C.W.); \\ zl1571382260@gmail.com (X.L.) \\ 3 Heilongiiang Key Laboratory of Molecular Design and Preparation of Flame Retarded Materials, College of \\ Science, Northeast Forestry University, Harbin 150040, China; lixiaoli0903@nefu.edu.cn \\ * Correspondence: guoyum@cau.edu.cn; Tel.: +(86-010)-6273-3900
}

Received: 18 October 2019; Accepted: 20 November 2019; Published: 25 November 2019

\begin{abstract}
The therapeutic application of antimicrobial peptides (AMPs), a potential type of peptide-based biomaterial, is impeded by their poor antimicrobial activity and potential cytotoxicity as a lack of understanding of their structure-activity relationships. In order to comprehensively enhance the antibacterial and clinical application potency of AMPs, a rational approach was applied to design amphiphilic peptides, including head-to-tail cyclic, linear and D-proline antimicrobial peptides using the template $(\mathrm{IR})_{\mathrm{n}} \mathrm{P}(\mathrm{IR})_{\mathrm{n}} \mathrm{P}(n=1,2$ and 3). Results showed that these amphiphilic peptides demonstrated antimicrobial activity in a size-dependent manner and that cyclic peptide OIR3, which contained three repeating units (IR)3, had greater antimicrobial potency and cell selectivity than liner peptide IR3, DIR3 with D-Pro and gramicidin S (GS). Surface plasmon resonance and endotoxin neutralization assays indicated that OIR3 had significant endotoxin neutralization capabilities, which suggested that the effects of OIR3 were mediated by binding to lipopolysaccharides (LPS). Using fluorescence spectrometry and electron microscopy, we found that OIR3 strongly promoted membrane disruption and thereby induced cell lysis. In addition, an LPS-induced inflammation assay showed that OIR3 inhibited the pro-inflammatory factor TNF- $\alpha$ in RAW264.7 cells. OIR3 was able to reduce oxazolone-induced skin inflammation in allergic dermatitis mouse model via the inhibition of TNF- $\alpha$, IL-1 $\beta$ and IL- 6 mRNA expression. Collectively, the engineered head-to-tail cyclic peptide OIR3 was considerable potential candidate for use as a clinical therapeutic for the treatment of bacterial infections and skin inflammation.
\end{abstract}

Keywords: head-to-tail cyclic antimicrobial peptides; cell selectivity; membrane; bactericidal mechanism; skin inflammation

\section{Introduction}

The continuous evolution of bacteria that has been accompanied by a reduced number of effective antibiotics has led to a global healthcare crisis [1]. The development of new antibiotics and novel approaches is critical for preventing an outbreak of drug-resistant bacteria, especially superbugs. Peptide-based biomaterials have been of increasing interest for use in the treatment antibionts, which has accelerated the development of nature-derived and synthetic peptides for therapeutic applications. 
Antimicrobial peptides (AMPs), endogenous immune components produced by various tissues of invertebrate and vertebrate animal, have been explored and used in a variety of biomedical applications, including as anti-infection agents, anticancer agents and biomedical coatings [2].

AMPs can selectively target and disintegrate bacterial membranes via electrostatic interactions and insertion into membrane lipid domains, leading to cell death; this is achieved through direct interaction with the cell membrane of bacteria, hence avoiding potential forms of resistance [3,4]. A recent study found that a new peptide derived from cathelicidin from Bungarus fasciatus was a competent candidate to be a novel antimicrobial compound for use against methicillin-resistant Staphylococcus aureus [5]. An in vivo study demonstrated that antiadhesive, antimicrobial peptide surface coatings can prevent bacterial adhesion and planktonic bacterial growth, thereby inhibiting catheter-associated infections in a murine urinary infection model [6]. However, there are technological hurdles impeding the therapeutic application of peptide-based biomaterials, including the high cost of isolation, potential systemic toxicity, instability and poor biocompatibility with host cells [7]; particularly, naturally secreted defenses could be compromised by natural peptides and their derivatives, possibly causing a serious public health problem. Therefore, the optimization of peptide molecular structures to enhance cell selectivity and anti-inflammatory ability and decrease the cost of production has become a principal challenge in the exploration of a new generation of antimicrobial drugs.

At present, more than 40 cyclic peptide drugs are applied in clinical practice with a great potential application effect [8]. AMPs with a restrained skeleton, especially a head-to-tail cyclic structure, can be utilized in developing novel antimicrobial drugs with increased activity [9]. A recent study found that rational design of head-to-tail cyclic peptides could be utilized to develop drug-like peptides as potent therapeutic Nrf2 activators [10]. Additionally, the cyclization of peptides can enhance their stability, resistance to exo- and (to some extent) endo-peptidases, binding affinity and selectivity towards target biomolecules; therefore, cyclic peptides have been actively investigated for use as biochemical tools and therapeutic agents [11]. In view of the condition-resistance stability of cyclic peptides and their high penetration efficiency, cyclic peptides are considered as ideal candidates for use as antibacterial drugs [12].

The most highly representative head-to-tail cyclic antimicrobial peptide is gramicidin $\mathrm{S}$ (GS) (cyclo(Val-Orn-Leu-DPhe-Pro)2), which is a cyclic decapeptide isolated from the bacterium Bacillus brevis [13]. GS has strong antimicrobial activity, especially towards Gram-positive bacteria and some pathogenic fungi. However, GS not only acts on bacterial membranes, but also on the membranes of mammalian cells such as erythrocytes [14]. For this reason it is limited in its use as an antibiotic in clinical medicine, the food industry and animal husbandry. The design strategies used for cyclic peptide therapeutics are generally limited by a poor understanding of sequence-structure relationships. Herein, we report the design of a simplified head-to-tail cyclic polypeptide as a biomaterial-associated antimicrobial, in order to tackle the problem of the high cytotoxicity of cyclic peptide-based drugs as well as to investigate the relationships between biological activity, conformation and modification. We designed a series of head-to-tail cyclic peptides, OIR1, OIR2 and OIR3, using the template sequence $(\mathrm{IR})_{\mathrm{n}} \mathrm{P}(\mathrm{IR})_{\mathrm{n}} \mathrm{P}(n=1,2$ and 3$)$. The peptide sequences consist of the hydrophobic amino acid isoleucine (Ile; I) and the hydrophilic amino acid arginine (Arg; R). In addition, these cyclic peptides were decyclized to obtain linear counterpart peptides IR1, IR2 and IR3. In addition, in order to obtain antimicrobial peptides with high bacterial cell selectivity $[15,16]$, we also substituted the L-Pro amino acids in IR1, IR2 and IR3 with D-Pro to generate the peptides DIR1, DIR2 and DIR3, respectively. The secondary conformations of the engineered peptides were characterized both in aqueous solution and in a simulated membrane environment using circular dichroism spectroscopy (CD). The antimicrobial activity of various salt ions and serum added at physiological concentration was measured using the minimum inhibitory concentration (MIC) method, and hemolytic activity and cytotoxicity was also determined. Peptide membrane interactions were investigated using fluorescence, flow cytometry and electron microscopy. We also developed a model of skin inflammation to explore the inhibitory effect of cyclic antimicrobial peptides on various inflammatory factors. This study had 
two main objectives: (1) to investigate the effect of peptides with varying lengths and secondary structures, including head-to-tail cyclic, decyclized and D-proline peptides, on antimicrobial potency and cell selectivity; and (2) to comprehensively evaluate the antibacterial potency and ability to inhibit skin inflammation of the engineered antimicrobial peptides, while developing synthetic peptide-based strategies to generate effective AMPs.

\section{Results}

\subsection{Design and Characterization of the Peptides}

In this experiment, cyclic, linear and D-proline antimicrobial peptides were designed based on the IR-rich template sequence (IR) ${ }_{n} \mathrm{P}(\mathrm{IR})_{\mathrm{n}} \mathrm{P}(n=1,2$ and 3$)$. The $\beta$-sheet conformation created an amphiphilic structure between the hydrophobic Ile side chains existing in a nonpolar face of the cyclic peptide molecule and the cationic Arg side chains, which is considered to be essential for its bioactivity. By decyclizing the cyclic peptides, we obtained linear counterpart peptides IR1, IR2 and IR3. We replaced the L-Pro amino acids in IR1, IR2 and IR3 with D-Pro to obtain the peptides DIR1, DIR2 and DIR3, respectively. The secondary structures and molecular weights of the peptides were identified using mass spectrometry. The theoretical and the measured molecular weight, the net charge number, the retained time and the amino acid residue sequence of each engineered antimicrobial peptide are shown in Table 1. The peptide fidelity was first confirmed by MALDI-TOF MS as summarized in Figure S1. Results showed that there was a good agreement between the calculated and measured molecular weights, indicating that all of the antimicrobial peptides were synthesized accurately. The hydrophobicity of the peptides in solution is dependably mirrored by the HPLC retention times [17]. In this experiment, the retention times of OIR1, OIR2, OIR3, IR1, IR2, IR3, DIR1, DIR2 and DIR3 were 10.32, 10.66, 12.64, 10.28, 10.58, 12.4, 10.44, 10.60 and $12.82 \mathrm{~min}$, respectively, indicating that the hydrophobicity of OIR3, IR3 and DIR3 were higher than those of shorter peptides.

Table 1. Simplified head-to-tail cyclic polypeptide design and key physicochemical parameters.

\begin{tabular}{|c|c|c|c|c|c|c|c|}
\hline Peptides & $\mathrm{CN}^{\mathrm{a}}$ & Sequences & AA & TMW $^{\mathbf{b}}$ & $\mathrm{MMW}^{\mathrm{c}}$ & $\mathrm{NC}^{\mathrm{d}}$ & $\mathrm{RT}^{\mathrm{e}}$ (min) \\
\hline OIR1 & 1 & Cyclo-(IRPIRP) & 6 & 732.95 & 732.97 & +2 & 10.32 \\
\hline OIR2 & 2 & Cyclo-(IR) $)_{2} \mathrm{P}(\mathrm{IR})_{2} \mathrm{P}$ & 10 & 1271.62 & 1271.66 & +4 & 10.66 \\
\hline OIR3 & 3 & Cyclo-(IR) $)_{3} \mathrm{P}(\mathrm{IR})_{3} \mathrm{P}$ & 14 & 1810.34 & 1810.35 & +6 & 12.64 \\
\hline IR1 & 4 & IRPIRP & 6 & 750.94 & 750.90 & +2 & 10.28 \\
\hline IR2 & 5 & $(\mathrm{IR})_{2} \mathrm{P}(\mathrm{IR})_{2} \mathrm{P}$ & 10 & 1289.64 & 1289.60 & +4 & 10.58 \\
\hline IR3 & 6 & $(\mathrm{IR})_{3} \mathrm{P}(\mathrm{IR})_{3} \mathrm{P}$ & 14 & 1828.31 & 1828.35 & +6 & 12.40 \\
\hline DIR1 & 7 & $I^{\mathrm{D}} \mathrm{PIR}^{\mathrm{D}} \mathrm{P}$ & 6 & 750.94 & 750.95 & +2 & 10.44 \\
\hline DIR2 & 8 & $(\mathrm{IR})_{2}{ }^{\mathrm{D}} \mathrm{P}(\mathrm{IR})_{2}{ }^{\mathrm{D}} \mathrm{P}$ & 10 & 1289.64 & 1289.60 & +4 & 10.60 \\
\hline DIR3 & 9 & $(\mathrm{IR})_{3}{ }^{\mathrm{D}} \mathrm{P}(\mathrm{IR})_{3}{ }^{\mathrm{D}} \mathrm{P}$ & 14 & 1828.31 & 1828.35 & +6 & 12.82 \\
\hline
\end{tabular}

${ }^{a}$ Compound number. ${ }^{\mathrm{b}}$ Theoretical molecular weight. ${ }^{\mathrm{c}}$ Measured molecular weight (measured by mass spectroscopy). ${ }^{\mathrm{d}}$ Net charge. $\mathrm{e}$ Retention time (RT; min). HPLC retention time was determined using a $4.6 \mathrm{~mm} \times 250 \mathrm{~mm}$ Venusil MP C18-5 column (Waters, Milford, MA, USA) at a wavelength of $220 \mathrm{~nm}$ with a linear acetonitrile gradient from $15 \%$ to $45 \%$ in $30 \mathrm{~min}$ with buffer A ( $0.1 \%$ trifluoroacetic acid in acetonitrile) and buffer B $(0.1 \%$ trifluoroacetic acid in water) at a flow rate of $1 \mathrm{~mL} / \mathrm{min}$.

\subsection{Circular Dichroism Spectroscopic Analysis}

CD spectroscopy of the all engineered peptides revealed their secondary structures in aqueous solution and in a membrane-mimetic environment. The $\mathrm{CD}$ spectrum of the engineered peptides were determined in different liquid environment including $10 \mathrm{mM}$ sodium phosphate buffer ( $\mathrm{pH} 7.4), 50 \%$ TFE or $30 \mathrm{mM}$ of SDS micelles (Figure 1). In aqueous solution, each of the engineered peptides, with the exception of DIR1, appeared to assume an unordered conformation. In the presence of $50 \%$ TFE, DIR1 and DIR2 more tended to be in the $\beta$-sheet conformation. The CD spectrum with the maximum value of near $190 \mathrm{~nm}$ and the minimum value near $216 \mathrm{~nm}$ indicated that DIR3 showed more $\beta$-hairpin structure [18]. Other peptides (except DIR1, DIR2 and DIR3) showed evidence of the presence of 
a sub-population displaying a $\beta$-hairpin conformation that was distinguished by a negative ellipticity near $205 \mathrm{~nm}$ and a crossover at $200 \mathrm{~nm}$ [19]. In the presence of $30 \mathrm{mM}$ anionic SDS, IR1, IR2 and IR3 each displayed characteristics of an unordered conformation, while OIR1, OIR2, OIR3 and DIR3 each appeared to have a population that assumed a $\beta$-hairpin conformation as described above [19]. DIR1 assumed an obvious $\beta$-sheet conformation and the DIR2 spectra indicated the presence of a significantly greater number of $\beta$-turns.

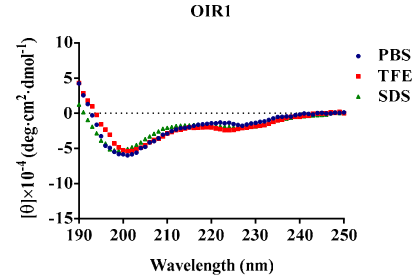

IR1

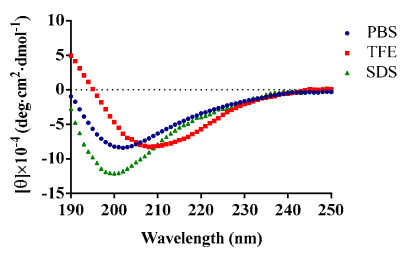

DIR1

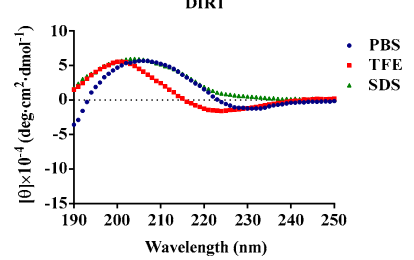

OIR2

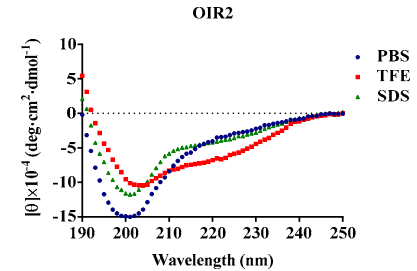

IR2

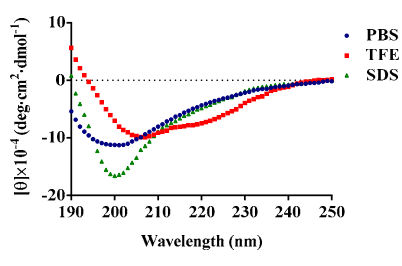

DIR2

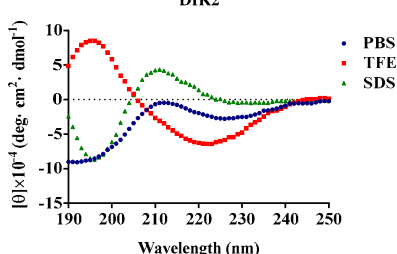

OIR3

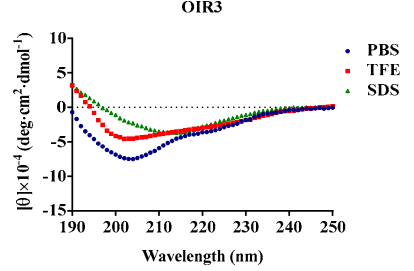

IR3

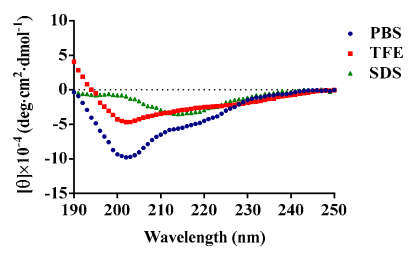

DIR3

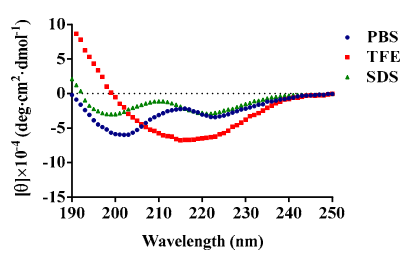

Figure 1. The circular dichroism (CD) spectra of the engineered peptides. The peptides were dissolved in $10 \mathrm{mM}$ sodium phosphate buffer ( $\mathrm{pH} 7.4), 30 \mathrm{mM}$ SDS and 50\% (v/v) trifluoroethanol. The mean residue ellipticity was plotted against wavelength. The values from three scans were averaged per sample, and the peptide concentrations were fixed at $150 \mu \mathrm{M}$.

\subsection{Antimicrobial and Hemolytic Activities and Selectivities}

As shown in Table 2, the antibacterial activity of the engineered peptides was detected against both Gram-positive bacteria and Gram-negative bacteria. Results showed that the MIC of OIR1, IR1 and DIR1 in the presence of Gram-positive and Gram-negative bacteria was greater than $128 \mu \mathrm{M}$. As the length of the peptide chain increased, its antimicrobial activity also increased. Peptides containing three repeating units (IR3) had the highest antimicrobial activity, especially the cyclic peptide OIR3. The antimicrobial activity of IR3 and DIR3 was lower than that of OIR3, indicating that the linearization of the cyclic peptide OIR3 and the substitution with D-proline decreased the peptides antimicrobial activity. Cyclic peptide OIR3 displayed the greatest antibacterial activity, with at GM MIC of 3.5-4.0 $\mu \mathrm{M}$, comparable to that of the broad-spectrum antibiotics GS $(\mathrm{GM}=2-6.1 \mu \mathrm{M})$, chloramphenicol $(\mathrm{CM}$; $\mathrm{GM}=18.4-22.6 \mu \mathrm{M})$, colistin sulfate $(\mathrm{CS} ; \mathrm{GM}=0.8-76.1 \mu \mathrm{M})$ and penicillin sodium (PS; $\mathrm{GM}=$ 13.5-24.3 $\mu \mathrm{M}$ ). The results of hemolytic activities of the peptides against human erythrocytes (Table 2 and Figure 2A) confirm that none of the engineered peptides displayed hemolytic activity, even at the highest concentration of $128 \mu \mathrm{M}$, while the control cyclic peptide GS exhibited a high level of hemolytic activity. 
Table 2. Antibacterial and hemolytic activities of the engineered peptides and antibiotics.

\begin{tabular}{|c|c|c|c|c|c|c|c|c|c|c|c|c|c|}
\hline \multirow{2}{*}{ Strains } & \multicolumn{10}{|c|}{$\operatorname{MICs}^{a}(\mu \mathrm{M})$} & \multirow[b]{2}{*}{$\mathrm{CH}^{\mathrm{b}}$} & \multirow[b]{2}{*}{$\mathrm{CS}^{\mathrm{c}}$} & \multirow[b]{2}{*}{ PS $^{d}$} \\
\hline & OIR1 & OIR2 & OIR3 & IR1 & IR2 & IR3 & DIR1 & DIR2 & DIR3 & GS & & & \\
\hline \multicolumn{14}{|l|}{ Gram-negative } \\
\hline E. coli 25922 & $>128$ & 64 & 2 & $>128$ & $>128$ & 16 & $>128$ & 128 & 4 & 4 & 16 & 0.5 & 128 \\
\hline E. coli UB 1005 & $>128$ & 64 & 2 & $>128$ & $>128$ & 8 & $>128$ & 128 & 4 & 4 & 4 & 0.5 & 64 \\
\hline P. aeruginosa 27853 & $>128$ & $>128$ & 8 & $>128$ & $>128$ & 8 & $>128$ & $>128$ & 8 & 4 & $>128$ & 0.5 & 128 \\
\hline S. typhimurium 7731 & $>128$ & $>128$ & 4 & $>128$ & $>128$ & 16 & $>128$ & $>128$ & 4 & 8 & 8 & 0.5 & 0.5 \\
\hline $\begin{array}{l}\text { S. typhimurium } 14028 \\
\text { Gram-positive }\end{array}$ & $>128$ & $>128$ & 4 & $>128$ & $>128$ & 16 & $>128$ & $>128$ & 16 & 16 & 16 & 4 & 16 \\
\hline S. aureus 29213 & $>128$ & $>128$ & 4 & $>128$ & $>128$ & 64 & $>128$ & $>128$ & 8 & 2 & 8 & 64 & 64 \\
\hline S. aureus 25923 & $>128$ & $>128$ & 4 & $>128$ & $>128$ & 64 & $>128$ & $>128$ & 64 & 2 & 32 & 64 & 32 \\
\hline MRSA43300 $\mathrm{e}^{\mathrm{e}}$ & $>128$ & $>128$ & 4 & $>128$ & $>128$ & 64 & $>128$ & $>128$ & 64 & 2 & 32 & 64 & 32 \\
\hline S. epidermidis 12228 & $>128$ & $>128$ & 4 & $>128$ & $>128$ & $>128$ & $>128$ & $>128$ & 128 & 2 & 32 & 128 & 0.5 \\
\hline nGM (-) $\mathrm{f} 1$ & 256 & 147.0 & 3.5 & 256 & 256 & 12.1 & 256 & 194.0 & 6.1 & 6.1 & 18.4 & 0.8 & 24.3 \\
\hline $\operatorname{pGM}(+)^{f 2}$ & 256 & 256 & 4.0 & 256 & 256 & 90.5 & 256 & 256 & 45.3 & 2 & 22.6 & 76.1 & 13.5 \\
\hline $\mathrm{tGM}^{\mathrm{f} 3}$ & 256 & 188.1 & 3.7 & 256 & 256 & 22.6 & 256 & 219.5 & 14.8 & 3.7 & 20.2 & 5.9 & 18.7 \\
\hline $\mathrm{MHC}_{5} \mathrm{~g}$ & $>128$ & $>128$ & $>128$ & $>128$ & $>128$ & $>128$ & $>128$ & $>128$ & $>128$ & 8 & $>128$ & $>128$ & $>128$ \\
\hline $\mathrm{nSI}(-) \mathrm{h} 1$ & 1.0 & 1.7 & 73.1 & 1.0 & 1.0 & 21.2 & 1.0 & 1.3 & 42.0 & 1.3 & 13.9 & 320.0 & 10.5 \\
\hline pSI (+) h2 & 1.0 & 1.0 & 64.0 & 1.0 & 1.0 & 2.8 & 1.0 & 1.0 & 5.7 & 4.0 & 11.3 & 3.4 & 19.0 \\
\hline $\mathrm{tSI}^{\mathrm{h} 3}[20,21]$ & 1.0 & 1.4 & 69.2 & 1.0 & 1.0 & 11.3 & 1.0 & 1.2 & 17.3 & 2.2 & 12.7 & 43.4 & 13.7 \\
\hline
\end{tabular}

${ }^{a}$ Minimum inhibitory concentrations (MICs) were determined as the lowest concentration of peptide that prevented visible turbidity. ${ }^{\mathrm{b}}$ Chloramphenicol. ${ }^{\mathrm{c}}$ Colistin Sulfate. ${ }^{\mathrm{d}}$ Penicillin Sodium. ${ }^{\mathrm{e}}$ Methicillin-resistant Staphylococcus aureus. ${ }^{\mathrm{f} 1} \mathrm{nGM}(-)$ was the geometric mean of the peptide MICs against gram-negative strains tested. ${ }^{\mathrm{f} 2} \mathrm{pGM}(+)$ was the geometric mean of the peptide MICs against gram-positive strains tested. ${ }^{\mathrm{f3}} \mathrm{tGM}$ was the geometric mean of the peptide MICs against all the 9 bacteria tested. ${ }^{3} \mathrm{MHC}_{5}$ was the minimum hemolytic concentration that that induced $\geq 5 \%$ hemolysis of human red blood cell. When no detectable hemolytic activity was observed at $128 \mu \mathrm{M}$, a value of $256 \mu \mathrm{M}$ was used to calculate the selectivity index. ${ }^{\mathrm{h} 1} \mathrm{nSI}(-)$ was the selectivity index that was calculated as $\mathrm{MHC}_{5} / \mathrm{GM}(-)$. ${ }^{\mathrm{h} 2} \mathrm{pSI}(+)$ was the selectivity index that was calculated as $\mathrm{MHC}_{5} / \mathrm{GM}(+) .{ }^{\mathrm{h} 3}$ tSI was the total selectivity index that was calculated as $\mathrm{MHC}_{5} / \mathrm{TGM}$.

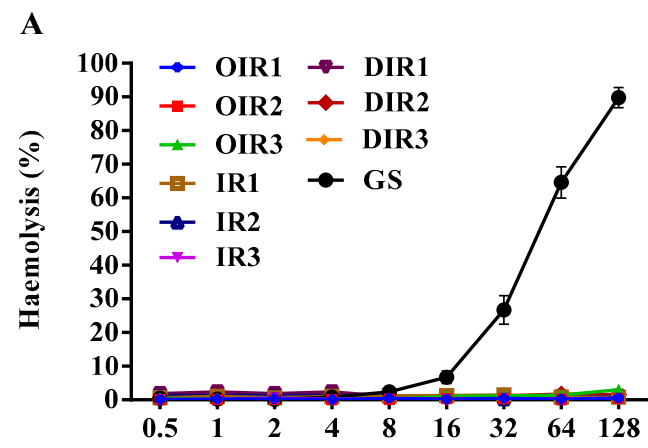

B

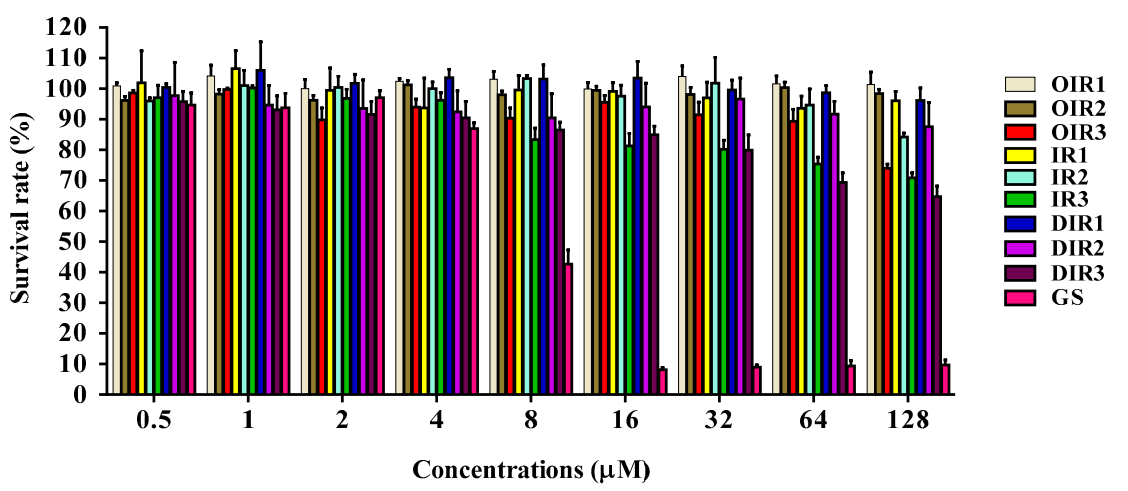

Figure 2. (A) Hemolytic activity of the engineered peptides against human red blood cells (hRBCs). The hRBCs were incubated with equal amounts of the respective peptides dissolved in PBS for $1 \mathrm{~h}$ at $37^{\circ} \mathrm{C}$. (B) Cytotoxicity of the engineered peptides against RAW264.7. The cells were incubated with various concentrations $(0.5-128 \mu \mathrm{M})$ of peptides for $24 \mathrm{~h}$, and the cell viability was determined by the MTT assay. Data shown are three independent experiments. 
To investigate the cell selectivity of novel antimicrobials, the total selectivity index (TSI) was calculated as the ratio of the minimal hemolysis concentration (MHC) to the geometric mean (GM) of the MIC values (Table 2). Cyclic peptide OIR3 displayed the greatest TI (69.2), which was four-fold greater than that of the linear counterpart peptide IR3 (11.3) or D-Pro peptide DIR3 (17.3). This demonstrated that the cyclic peptide OIR3 had a greater selectivity towards microorganisms versus erythrocytes, suggesting that it may be used during a larger treatment window.

\subsection{Cytotoxicity}

The results of cytotoxicity testing of the engineered peptides displayed that the length of the peptide slightly affected its cytotoxic activity (Figure 2B). The survival rates of RAW264.7 cells exposed to OIR1, OIR2 and OIR3 were $99 \%, 95 \%$ and $70 \%$, respectively, at the highest concentration of $128 \mu \mathrm{M}$; with a decrease in the OIR3 concentration, the cytotoxicity decreased, indicating that OIR3 showed almost no toxicity towards mammalian cells. The survival rates of cells exposed to the linear peptide IR3 at the maximum concentration was 70\%, indicating that linearization of the cyclic peptide OIR3 had no effect on its toxicity in cells, while the cell survival upon exposure to DIR3 at the maximum concentration was $65 \%$, indicating that the presence of D-proline slightly increased the toxicity of the peptide. In line with its MHC value, the control peptide GS was highly toxic towards mammalian cells.

\subsection{Salt Sensitivity and Serum Stability}

Based on the MIC and MHC values, the salt sensitivity of peptides was detected by adding salt ions of varying physiological concentrations. The addition of monovalent $\left(\mathrm{Na}^{+}, \mathrm{NH}_{4}{ }^{+}\right.$and $\left.\mathrm{K}^{+}\right)$, divalent $\left(\mathrm{Mg}^{2+}, \mathrm{Ca}^{2+}\right.$, and $\left.\mathrm{Zn}^{2+}\right)$ and trivalent cations $\left(\mathrm{Fe}^{3+}\right)$ had little effect (Table 3). The antibacterial activity of OIR3 against Escherichia coli (E. coli) and S. aureus was slightly reduced in the presence of $\mathrm{Na}^{+}$and $\mathrm{Ca}^{2+}$. Interestingly, the antibacterial activity of IR3 against $S$. aureus was 1-2 times stronger in terms of its MIC value, indicating that the antibacterial activity of the IR3 by the linearization of OIR3 is more susceptible to salt ions.

Table 3. MIC ${ }^{\mathrm{a}}$ values of the engineered peptides in the presence of physiological salts and serum.

\begin{tabular}{|c|c|c|c|c|c|c|c|c|c|c|}
\hline Peptides & Control $^{b}$ & $\mathrm{NaCl}^{\mathrm{b}}$ & $\mathrm{KCl}^{\mathrm{b}}$ & $\mathrm{NH}_{4} \mathrm{Cl}^{\mathrm{b}}$ & $\mathrm{MgCl}_{2}{ }^{\mathrm{b}}$ & $\mathrm{CaCl}_{2}{ }^{\mathrm{b}}$ & $\mathrm{ZnCl}_{2}{ }^{\mathrm{b}}$ & $\mathrm{FeCl}_{3} \mathrm{~b}$ & \multicolumn{2}{|c|}{ Serum $^{c}$} \\
\hline \multicolumn{9}{|c|}{ Gram-negative strain E. coli ATCC 25922} & $25 \%$ & $50 \%$ \\
\hline OIR3 & 2 & 4 & 2 & 2 & 2 & 4 & 2 & 2 & 4 & 8 \\
\hline IR3 & 16 & 32 & 16 & 16 & 16 & 32 & 16 & 16 & 32 & 64 \\
\hline DIR3 & 4 & 16 & 16 & 8 & 8 & 16 & 8 & 8 & 8 & 16 \\
\hline GS & 4 & 16 & 4 & 4 & 8 & 16 & 4 & 4 & 32 & 64 \\
\hline \multicolumn{11}{|c|}{ Gram-positive strain S. aureus ATCC 29213} \\
\hline OIR3 & 4 & 8 & 4 & 4 & 4 & 8 & 4 & 4 & 8 & 16 \\
\hline IR3 & 64 & 32 & 16 & 16 & 16 & 32 & 16 & 16 & 32 & 64 \\
\hline DIR3 & 8 & 16 & 8 & 8 & 8 & 16 & 8 & 8 & 8 & 16 \\
\hline GS & 2 & 2 & 4 & 2 & 2 & 2 & 2 & 2 & 32 & $>64$ \\
\hline
\end{tabular}

${ }^{a}$ Minimum inhibitory concentrations (MIC) were determined as the lowest concentration of the peptides that inhibited bacteria growth. ${ }^{b}$ The final concentrations of $\mathrm{NaCl}, \mathrm{KCl}, \mathrm{NH}_{4} \mathrm{Cl}, \mathrm{MgCl}_{2}, \mathrm{CaCl}_{2}, \mathrm{ZnCl}_{2}$, and $\mathrm{FeCl}_{3}$ were $150 \mathrm{mM}, 4.5 \mathrm{mM}, 6 \mu \mathrm{M}, 1 \mathrm{mM}, 2 \mathrm{mM}, 8 \mu \mathrm{M}$, and $4 \mu \mathrm{M}$, respectively, and the control MIC values were determined in the absence of these physiological salts (salt ion concentration in normal human blood). ${ }^{\mathrm{c}}$ Human blood serum was inactivated by heat treatment for $15 \mathrm{~min}$ at $56^{\circ} \mathrm{C}$. MICs in the presence of $25 \%$ and $50 \%$ human blood serum were determined.

To further evaluate the serum stability of the engineered peptides, their antimicrobial activity against Gram-negative E. coli and Gram-positive S. aureus in the presence of $25 \%$ or $50 \%$ serum were measured (Table 3). The results displayed that the MICs of the engineered peptides were increased to varying degrees. The serum had a slight effect on the antimicrobial activity of OIR3 and DIR3, while IR3 and GS lost most of their antibacterial activity against E. coli and S. aureus. 


\subsection{Endotoxin Neutralization Activities}

Lipopolysaccharide (LPS), a main component of the endotoxin derived from the outer membrane of Gram-negative bacteria, plays a role in systemic inflammatory response syndrome. Previous studies demonstrated that AMPs could bind LPS to gain access to bacterial membranes and facilitate subsequent membrane disruption or translocation into bacteria [22,23]. We determined the LPS-binding ability of the engineered peptides OIR3, IR3, DIR3 and GS with a fluorescence-based displacement assay with BODIPY-TRcadaverine and polymyxin B, which has well-known strong LPS-binding capability, as a reference compound. As shown in Figure 3A, the engineered peptides OIR3, IR3, DIR3 and GS displayed a dosage-dependent increase in fluorescence intensity, clearly demonstrating their ability to bind to LPS. Of all of the engineered peptides, the binding ability of the cyclic peptide OIR3 had the strongest binding ability for IR3 and DIR3. OIR3 had 81\% LPS-binding activity at low peptide concentration $(2 \mu \mathrm{M})$ and almost completely neutralized the LPS at $4 \mu \mathrm{M}(98 \%)$. At all concentrations tested, the combining ability of GS with LPS was relatively low, and the combining ability even at the highest concentration of $32 \mu \mathrm{M}$ was lower than that of OIR3 at $1 \mathrm{mM}$.

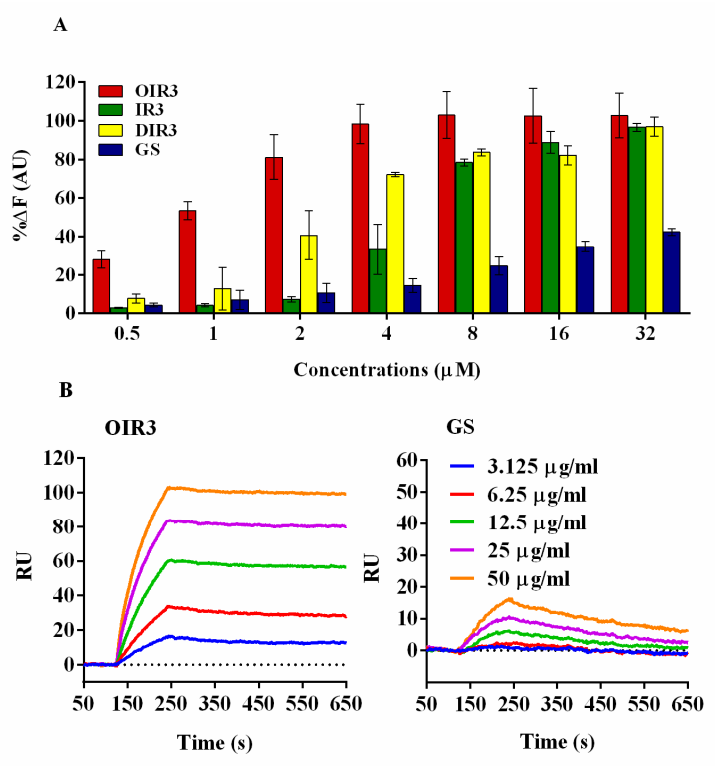

Figure 3. (A) The combining ability of OIR3 and gramicidin S (GS; $0.5 \mu \mathrm{M}, 1 \mu \mathrm{M}, 2 \mu \mathrm{M}, 4 \mathrm{mM}, 8 \mu \mathrm{M}$, $16 \mu \mathrm{M}$ and $32 \mu \mathrm{M}$ ) with lipopolysaccharide (LPS). (B) SPR spectroscopy of the interaction kinetics of the peptides and LPS. The peptides were immobilized on a CM5 sensor chip as a ligand, and LPS was diluted in a series of concentrations $(3.125,6.25,12.5,25$ and $50 \mu \mathrm{g} / \mathrm{mL})$. Data shown are three independent experiments.

We used Surface Plasmon Resonance (SPR) spectroscopy to further demonstrate the ability of OIR3 and GS to bind to LPS. As shown in Figure 3B, LPS rapidly binds to immobilized OIR3 and had a significant metrological dependency on the LPS concentration $(3.125-50 \mu \mathrm{g} / \mathrm{mL})$, while the control peptide GS demonstrated weak binding to LPS at high concentrations and almost no binding at the low concentrations (3.125 and $6.25 \mu \mathrm{g} / \mathrm{mL}$ ).

\subsection{Outer Membrane Permeability Assay}

The above results displayed that the cyclic peptide OIR3 had higher antibacterial activity and stability than other engineered peptides, and its antibacterial mechanism was further examined by evaluating its interaction with the cell membrane of bacterial. The hydrophobic fluorescent probe NPN is usually blocked by the outer membranes of bacterial cells and quenched under aqueous conditions, but it is taken up if the outer membranes of bacterial cells are permeabilized and shows intense fluorescence intensity in a hydrophobic environment. Results showed that the engineered peptides 
could permeabilize the outer membrane of Gram-negative bacteria and a concentration-dependent manner. The outer membrane permeability of OIR3 was more than $70 \%$ at concentrations greater than $4 \mu \mathrm{M}$, and higher than that of the control peptide GS (Figure 4).

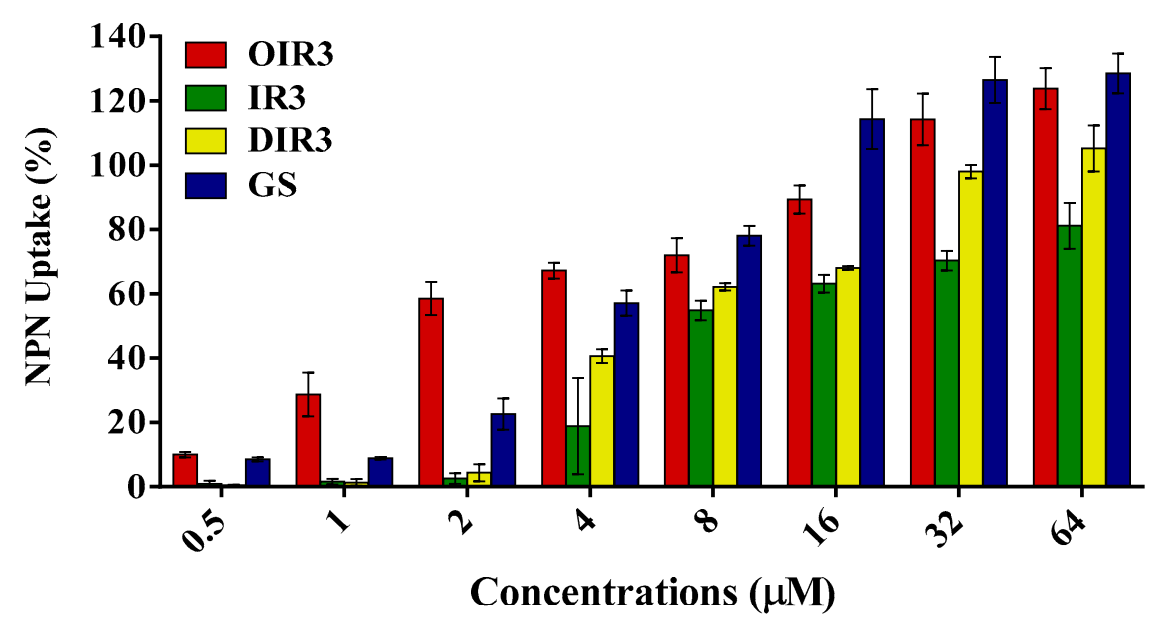

Figure 4. Outer membrane permeabilization assays of the engineered peptides. A $2 \mathrm{~mL}$ volume of $E$. coli UB1005 cells, diluted to $10^{5} \mathrm{CFU} / \mathrm{mL}$ in $5 \mathrm{mM}$ sodium HEPES buffer, was added to a quartz cuvette containing NPN to give a final concentration of $10 \mu \mathrm{M}$. Aliquots of peptides were added to the cuvette, and the fluorescence was recorded until there was no further increase in fluorescence. Data shown are three independent experiments.

\subsection{Inner Membrane Permeability Assay}

An o-nitrophenol- $\beta$-D-galactoside (ONPG) assay was performed to assess the inner membrane permeability of the engineered peptides (Figure 5). The results revealed that engineered peptide OIR3, IR3, DIR3 and GS showed inner membrane permeability in a time- and dosage-dependent manner. The cyclic peptide OIR3 had a higher endomembrane permeability activity than IR3, DIR3 and GS.
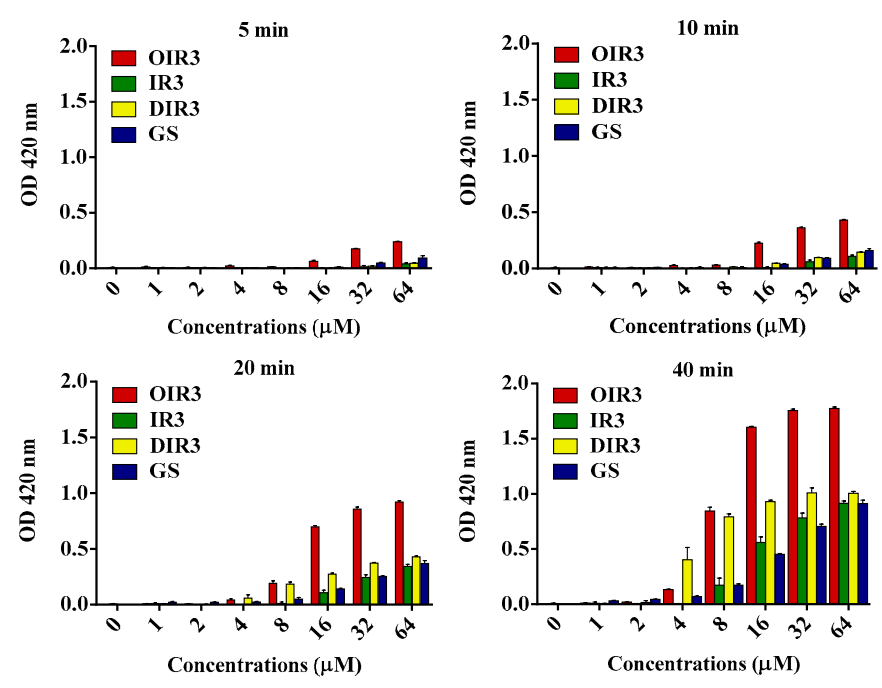

Figure 5. Inner membrane permeability of the engineered peptides. Hydrolysis of ONPG due to the release of cytoplasmic $\beta$-galactosidase of E. coli UB1005 treated with peptides OIR3, IR3, DIR3 and GS at a series of different time ( $5 \mathrm{~min}, 10 \mathrm{~min}, 20 \mathrm{~min}$ and $40 \mathrm{~min})$ and different concentration $(1 \mu \mathrm{M}, 2 \mu \mathrm{M}$, $4 \mu \mathrm{M}, 8 \mu \mathrm{M}, 16 \mu \mathrm{M}, 32 \mu \mathrm{M}$ and $64 \mu \mathrm{M})$ and measured spectroscopically at an absorbance of $420 \mathrm{~nm}$ as a function of time. 


\subsection{Cytoplasmic Membrane Electrical Potential Measurement}

A membrane potential-dependent probe (3, 3'-dipropylthiadicarbocyanine iodide; DiSC3-5) was adopted to evaluate the ability of engineered peptides to depolarize the bacterial cytoplasmic membrane. When the cytoplasmic membrane is permeable and destroyed, the membrane potential is eliminated, and released DiSC3-5 caused an increase in fluorescence. All of the detected peptides depolarized the cytoplasmic membrane of bacterial cells in a dosage-dependent manner (Figure 6). Compared with the other antimicrobial peptides, OIR3 induced cell membrane depolarization faster and more strongly.
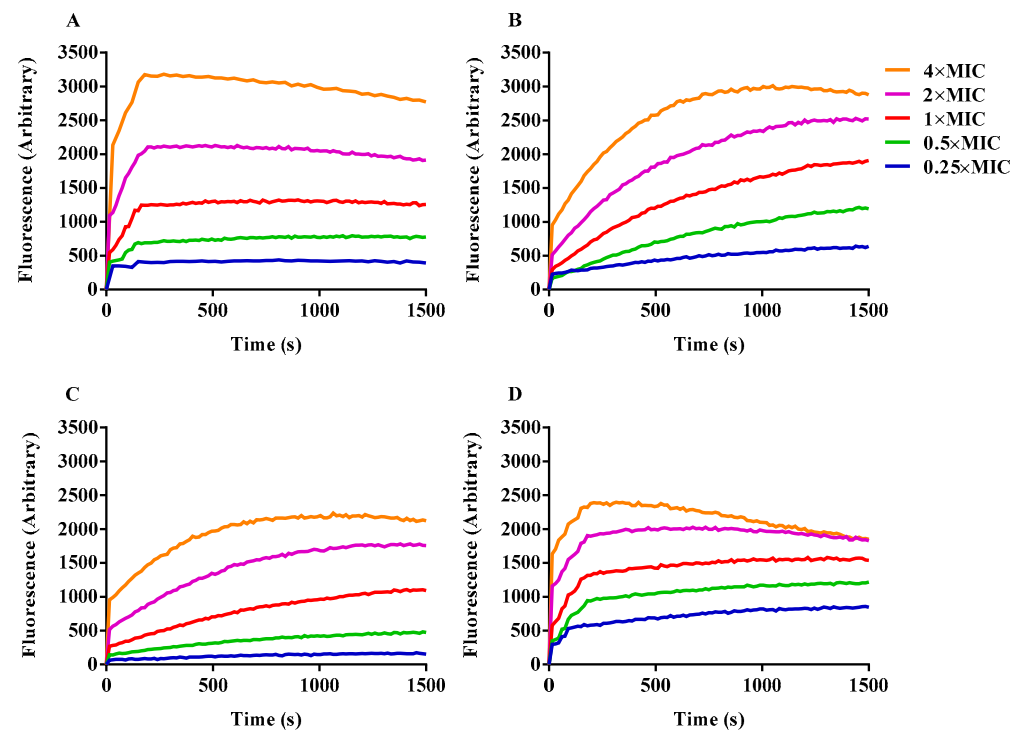

Figure 6. Cytoplasmic membrane depolarization of E. coli UB1005 was measured by using the membrane potential-sensitive dye, DiSC3-5 treated with the engineered peptides OIR3 (A), IR3 (B), DIR3 (C) and GS (D) at a series of different concentration $0.25 \times$ MIC, $0.5 \times$ MIC, $1 \times$ MIC, $2 \times$ MIC and $4 \times$ MIC.

\subsection{Flow Cytometry Analysis}

The fluorescent dye Propidium Iodide (PI) can enter a dead cell and combine with DNA to produce red fluorescence; subsequently, flow cytometry can be used to detect the intensity of the fluorescence release and determine the proportion of dead cells resulting from peptide exposure. Analysis of the results displayed that the control sample (A) contained only $2.2 \%$ PI-positive cells. The percentage of PI-positive cells due to exposure to OIR3 was 25\% (E, 1/2× MIC), 62\% (F, 1× MIC) and 76.4\% (G, $2 \times$ MIC). Treatment with GS resulted in $7.3 \%(B, 1 / 2 \times$ MIC), 37.8\% (C, $1 \times$ MIC) and 93.3\% (D, 2× MIC) PI-positive cells (Figure 7). Our data found that OIR3 caused a bigger accumulation of PI than GS at $\leq 1 \times$ MIC, while GS caused greater accumulation than OIR3 at 2× MIC. 

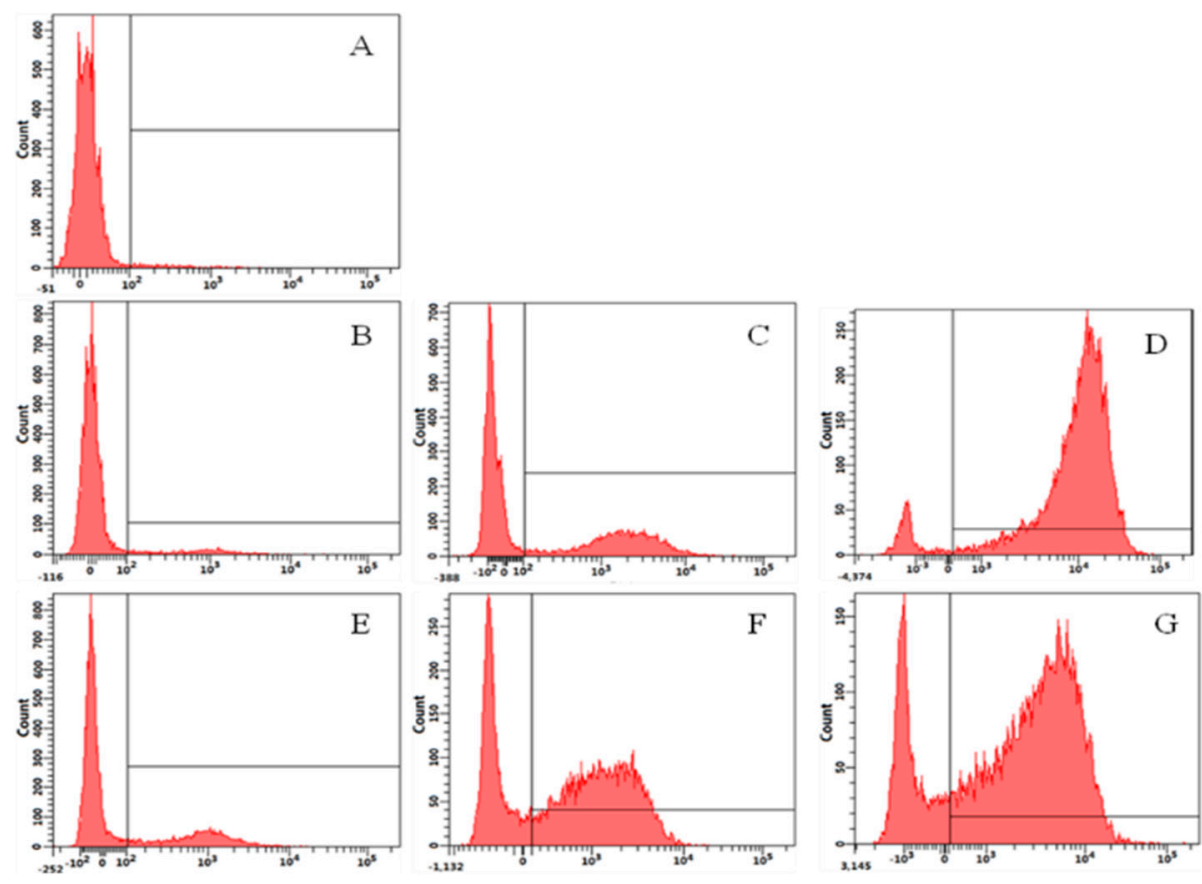

Figure 7. Flow cytometric analysis. Exponential phase E. coli cells were treated with GS, OIR3 and cellular fluorescence was analyzed by flow cytometry. The increments of the log fluorescence signal represent PI uptake resulting from peptide treatment. (A) No peptide, negative control; (B) GS $(1 / 2 \times$ MIC, $2 \mu \mathrm{M})$; (C) GS $(1 \times$ MIC, $4 \mu \mathrm{M})$; (D) GS $(2 \times$ MIC, $8 \mu \mathrm{M})$; (E) OIR3 $(1 / 2 \times$ MIC, $1 \mu \mathrm{M})$; (F) OIR3 $(1 \times \mathrm{MIC}, 2 \mu \mathrm{M})$ and $(\mathrm{G}) \mathrm{OIR} 3(2 \times \mathrm{MIC}, 4 \mu \mathrm{M})$.

\subsection{Scanning Electron Microscopy (SEM) and Transmission Electron Microscopy (TEM)}

The antimicrobial mechanisms utilized by the engineered peptides against E. coli 25,922 and $S$. aureus 29,213 cells were further analyzed by using SEM to study the transformation of morphological characteristics. The control cells, which were not treated with any peptides, displayed brilliant and smooth membrane surfaces (Figure 8A,D). However, when the bacterial cells are exposed to OIR3 and GS at $1 \times$ MIC, the S. aureus and E. coli cell membranes became rough and wrinkled and appeared destroyed. In order to further observe the changes in morphologic and internal microstructure of bacteria cell, TEM was adopted and the results that the control E. coli and S. aureus cells were smooth and complete (Figure 9A,D). After $1 \mathrm{~h}$ of treatment with both OIR3 and GS, the morphology of bacteria had undergone significant changes and there was evidence of cell membrane rupture and cytoplasmic leakage; in particular, the bacterial surfaces of cells treated with OIR3 appeared to have formed vesicular protuberances. 

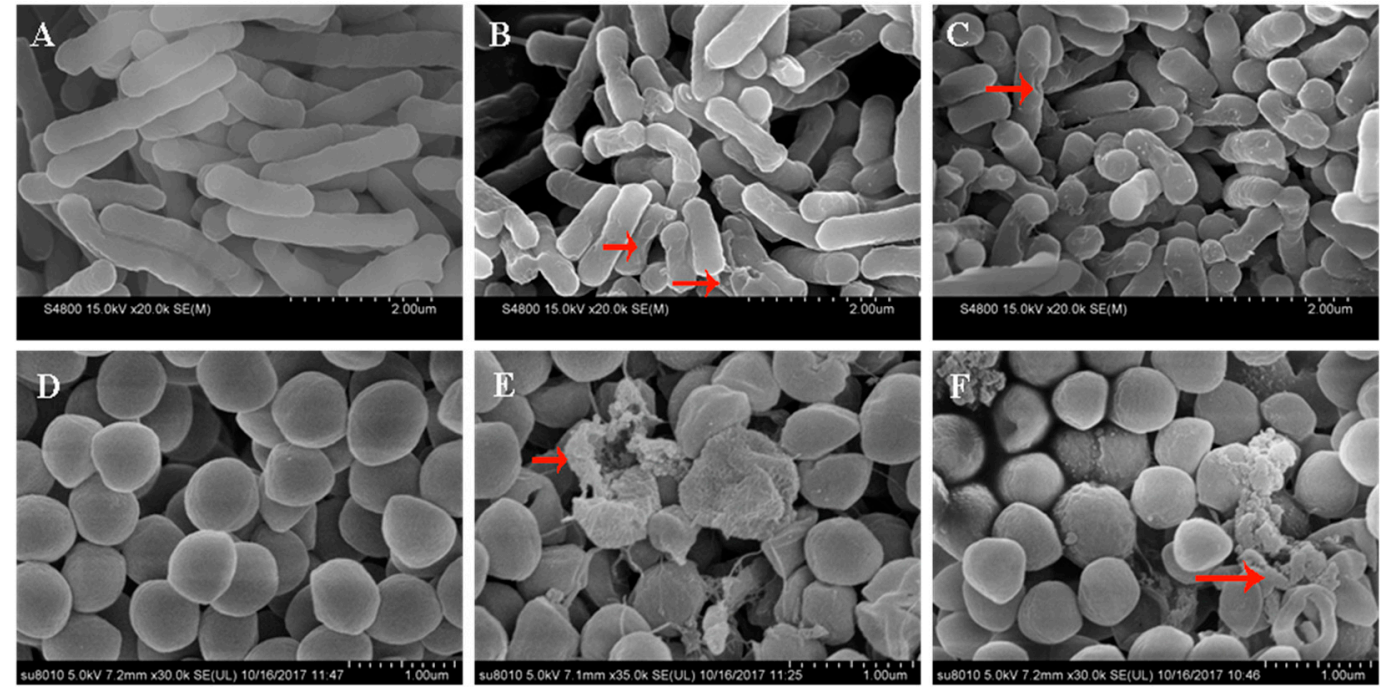

Figure 8. Scanning electron micrographs of E. coli 25,922 and S. aureus ATCC 29,213 treated with GS and OIR3. SEM micrographs of E. coli: (A) control, no peptides; (B) OIR3-treated, $2 \mu \mathrm{M}$ (C) GS-treated, $4 \mu \mathrm{M}$. SEM micrographs of S. aureus: (D) control, no peptides; (E) OIR3-treated, $4 \mu \mathrm{M}$ and (F) GS-treated, $2 \mu \mathrm{M}$. Scanning electron micrographs $E$. coli and S. aureus bacteria in mid-logarithmic growth were treated with peptides at $1 \times$ MIC for $1 \mathrm{~h}$. The red arrow indicates the difference from the control group.

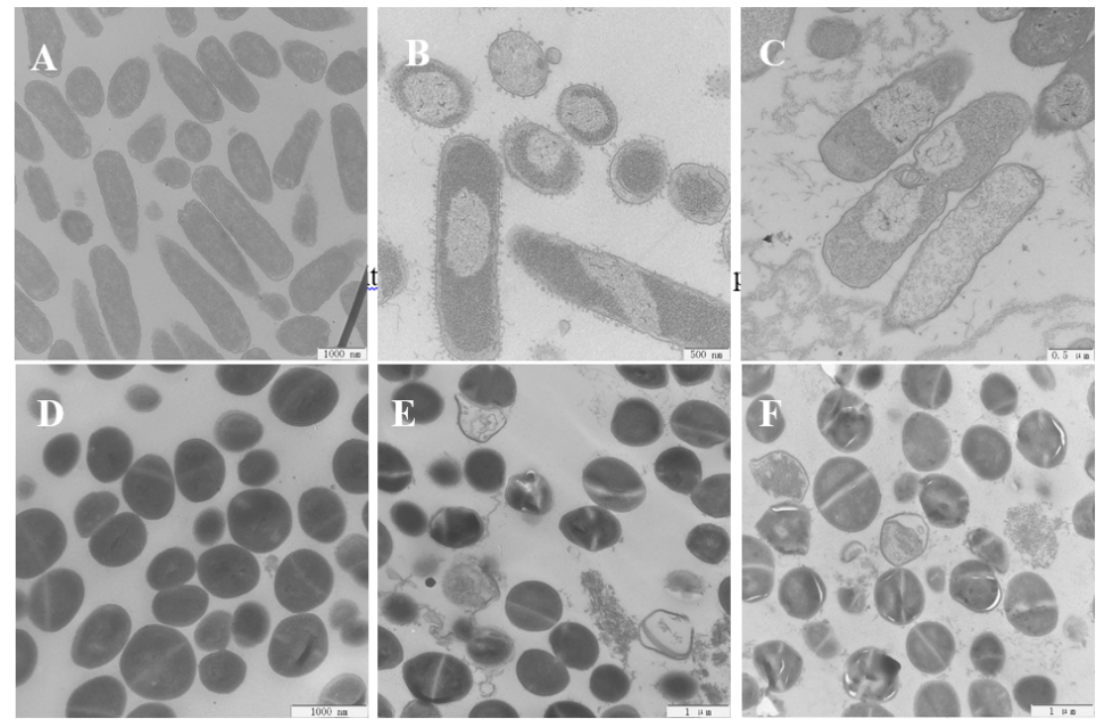

Figure 9. Transmission electron microscopy of E. coli 25,922 and S. aureus ATCC 29,213 treated with GS and OIR3. TEM micrographs of E. coli: (A) Control, no peptides. The scale is $1000 \mathrm{~nm}$. (B) OIR3-treated, $2 \mu \mathrm{M}$. The scale is $500 \mathrm{~nm}$. (C) GS-treated, $4 \mu \mathrm{M}$. The scale is $500 \mathrm{~nm}$. TEM micrographs of S. aureus at the scale of $1000 \mathrm{~nm}$ : (D) Control, no peptides. (E) OIR3-treated, $4 \mu \mathrm{M}$ and (F) GS-treated, $2 \mu \mathrm{M}$. TEM micrographs E. coli and S. aureus bacteria in mid-logarithmic growth were treated with peptides at $1 \times$ MIC for $1 \mathrm{~h}$.

\subsection{Swimming Motility Assays}

The flagella exist on the exterior of the cell wall of Gram-negative bacteria, which can impel the bacterial motility and chemotaxis that are crucial to the process of infection for many pathogenic bacteria. As shown in Figure 10, the engineered peptides OIR3, IR3 and DIR3 can significantly inhibit the swimming motility of $E$. coil cells at concentrations of $4 \mu \mathrm{M}$ and $8 \mu \mathrm{M}$. The control peptide GS produced almost no inhibition of motility at all tested concentrations. 


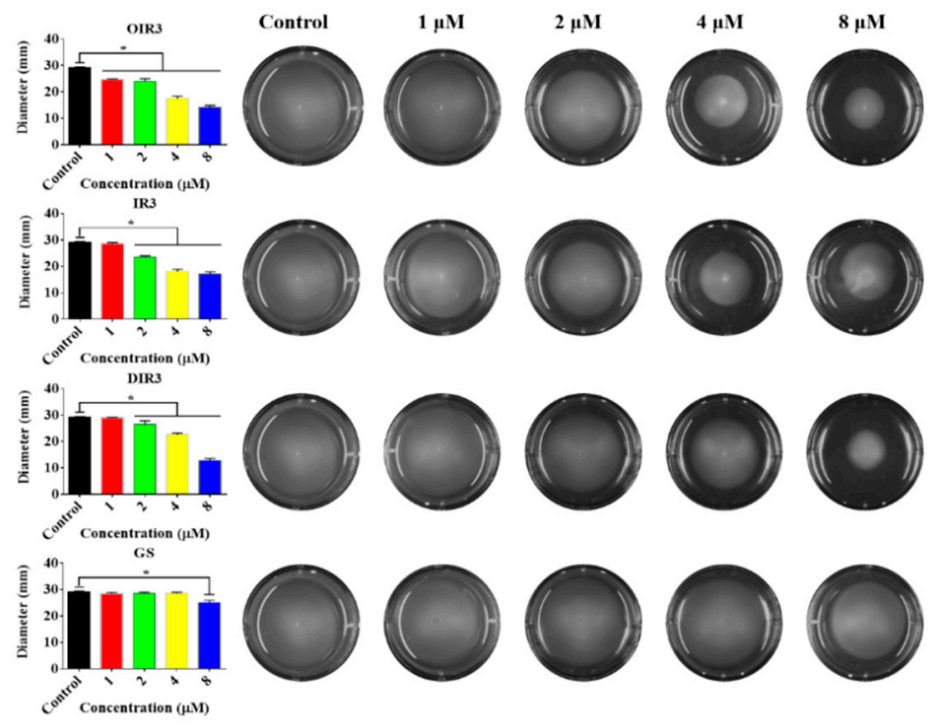

Figure 10. Swimming motility of E. coli ATCC 25,922 treated with OIR3, IR3, DIR3 and GS. Swim plates were prepared using $0.3 \%$ agar and inoculated from overnight cultures standardized to an optical density at $600 \mathrm{~nm}$ of 1.0 . Images were taken after $20 \mathrm{~h}$ incubation at $37^{\circ} \mathrm{C}$. Data shown are the mean \pm $\mathrm{SD}$ of three independent experiments. Bars with “*” represent significantly different mean values with $p<0.05$.

\subsection{Anti-Inflammatory Activities}

LPS-stimulated TNF- $\alpha$ production in the cytoplasm of RAW264.7 cells was determined using ELISA of mouse TNF- $\alpha$ performed with a commercial kit (Boster, Wuhan, China; Figure 11). The cyclic peptide OIR3 more strongly inhibited the expression of TNF- $\alpha$ in a dosage-dependent method than did either the linear peptide IR3 or the D-Pro-containing peptide DIR3 at all tested concentrations $(p<0.01)$. At low concentrations (peptide concentration below $8 \mu \mathrm{M}$ ), the cyclic peptide OIR3 had a stronger ability to inhibit the production of TNF- $\alpha$ than the control cyclic peptide GS. At high concentrations (peptide concentrations above $8 \mu \mathrm{M}$ ), the control loop peptide GS had cytotoxicity resulting in cell death and resulting in lower expression of TNF- $\alpha$.

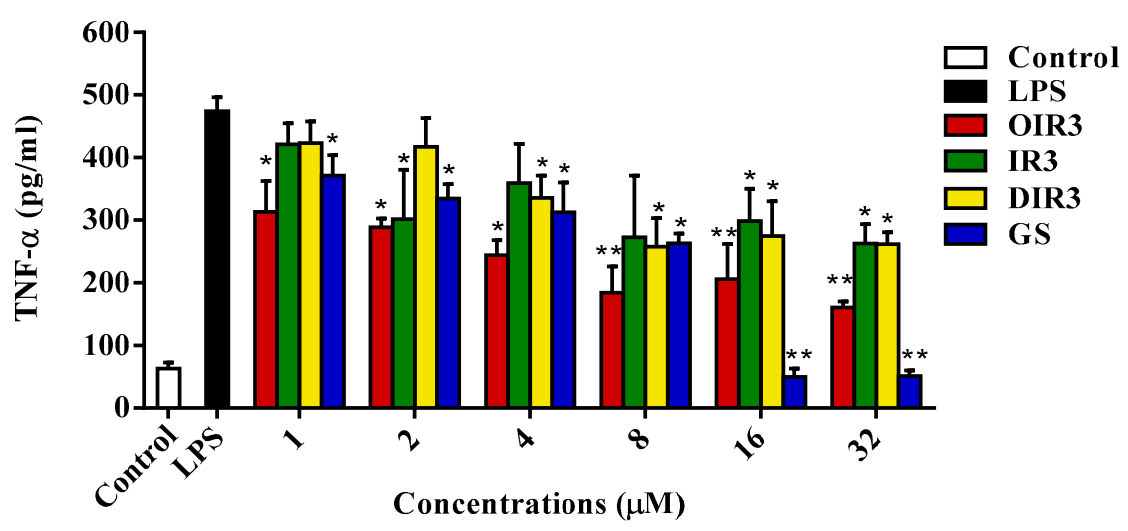

Figure 11. The inhibitory effects of OIR3, IR3, DIR3 and GS on LPS-stimulated TNF- $\alpha$ production in RAW264.7 cells. The levels of TNF- $\alpha$ in the cytoplasm were determined by ELISA using a commercial kit for mouse TNF- $\alpha$. Data shown are the mean \pm SD of three independent experiments. "**" represent significantly different mean values with $p<0.05$. " $* * *$ represent significantly different mean values with $p<0.01$. 


\subsection{Effects of Peptides on Oxazolone-Induced Skin Inflammation in Mice}

We further evaluated the anti-inflammatory activity of OIR3 during oxazolone-induced skin inflammation and compared it to that of GS and DXM. Ear thickness and ear punch weight were significantly increased in the disease model mice, compared to the untreated control mice. OIR3 significantly reduced ear thickness (Figure 12A) and ear punch weight (Figure 12B) in a dosage-dependent fashion, and at the highest concentration of $2 \%$ OIR3 produced the lowest ear thickness and ear punch weight, similarly to the group treated with DXM, while GS increased ear thickness and ear punch weight as its concentration increased. Histopathological evaluation of mouse ear tissue demonstrated that prominent epidermal hyperplasia caused by migration of inflammatory cells, including monocytes, granulocytes and macrophages, primarily into the dermis and as well as into the epidermis. According to gross and histological findings, ear edema was remarkably ameliorated in the ears of mice treated with both oxazolone and OIR3 compared to ears of mice treated only with GS (Figure 12C). Furthermore, the expression of mRNA of inflammatory cytokines TNF- $\alpha$, IL-1 $\beta$ and IL- 6 was significantly down-regulated by OIR3 (Figure 13). Sequences used for the amplification primers ( $5^{\prime}$ to $3^{\prime}$ orientation) were listed in Table 4 . These data suggested that OIR3 treatment could effectively attenuate skin inflammation.
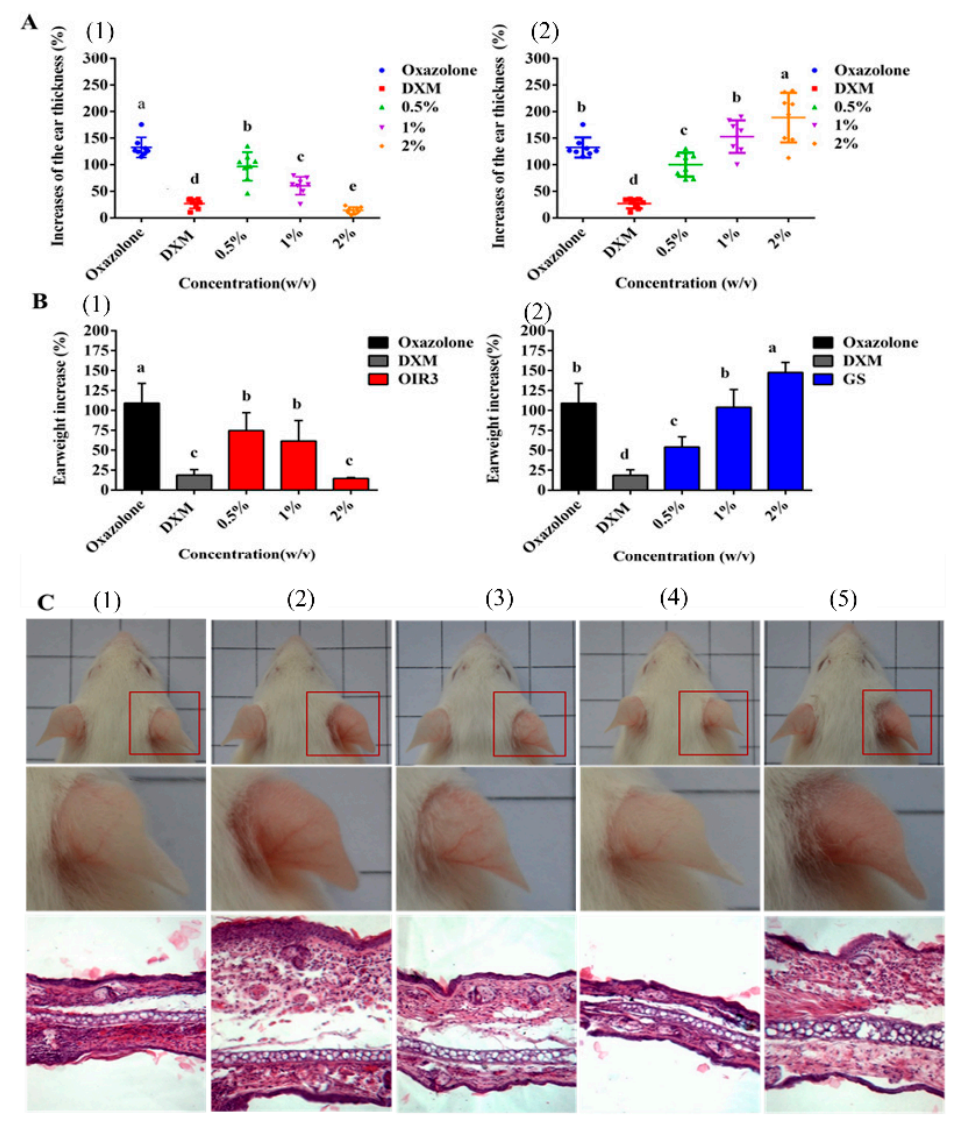

Figure 12. (A) Treatment with OIR3 attenuates oxazolone-induced ear skin inflammation of mice. Changes of ear thickness (1, OIR3; 2, GS) and (B) weights of ear punches (1, OIR3; 2, GS) were evaluated. (C) Gross findings of mice (upper panels) and microscopic findings of ear skin after H\&E staining (lower panels) at $24 \mathrm{~h}$ after treatment. (1), negative control (95\% ethanol); (2), positive control (oxazolone); (3), $1 \% \operatorname{DXM}(w / v) ;(4), 2 \%$ OIR3 $(w / v)$ and (5), $2 \%$ GS $(w / v)$. The error bars represent mean \pm SD. Data shown are the mean $\pm \mathrm{SD}$ of three independent experiments. Bars with different letters represent significantly different mean values with $p<0.05$. 

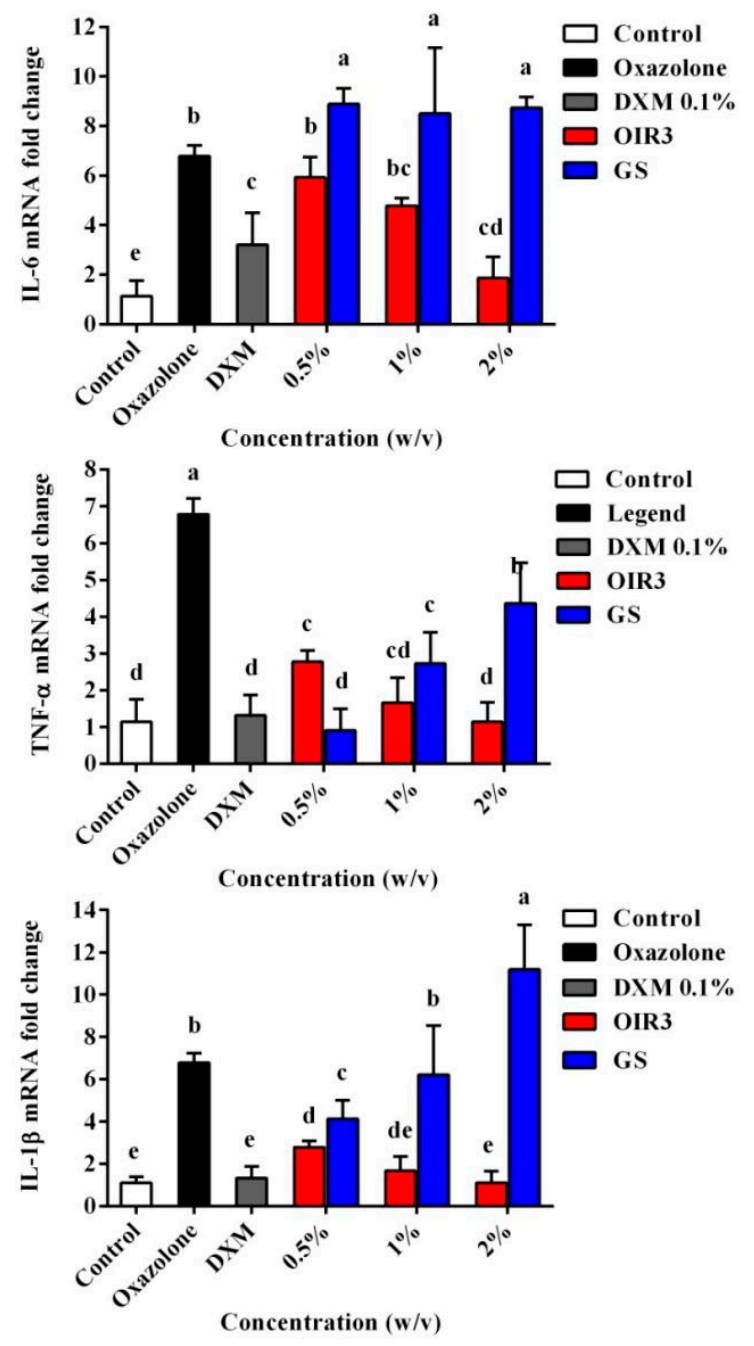

Figure 13. The expression of inflammatory cytokines TNF- $\alpha$, IL-6 and IL- $1 \beta$ mRNA in mouse ear tissues were determined. Data shown are the mean \pm SD of three independent experiments, and $a, b, c$, $\mathrm{d}$ and e represent a significant difference at a level of $p<0.05$.

Table 4. Sequence of the amplification primers in the $5^{\prime}$ to $3^{\prime}$ orientation.

\begin{tabular}{cc}
\hline Target Gene & Sequence $\left(5^{\prime}-\mathbf{3}^{\prime}\right)$ \\
\hline TNF- $\alpha$ & Forward: CCTATGTCTCAGCCTCTTCTCAT \\
& Reverse: CACTTGGTGGTTTGCTACGA \\
IL-6 & Forward: GGAGAGGAGACTTCACAGAGGA \\
& Reverse: ATTTCCACGATTTCCCAGAGA \\
IL-1 $\beta$ & Forward: TGAAATGCCACCTTTTGACAG \\
& Reverse: CCACAGCCACAATGAGTGATAC \\
mGAPDH & Forward: TGTTCCTACCCCCATGTGT \\
& Reverse: TGTGAGGGAGATGCTCAGTG \\
\hline
\end{tabular}

\section{Discussion}

Previous studies have shown that the structural changes in AMPs within various environments were related to their biological activities [24,25]. Secondary conformations of these engineered peptides in membrane-mimetic environments were revealed by distinct CD spectroscopic changes. In aqueous solution, most of the engineered peptides assumed an unstructured or random coil-type conformation, while in a membrane-mimetic environment, the active peptides OIR3 and DIR3 adopted a $\beta$-hairpin conformation (Figure 1). Conformational rearrangement of the decyclized peptide IR3 vanished 
in an SDS-containing environment that mimicked the amphiphilic environment within a biological phospholipid bilayer [26], which suggested that the decyclization of a peptide may be strongly associated with its reducing activity (Table 2). In the presence of TFE, D-Pro-containing AMPs DIR1 and DIR2 assumed an obvious $\beta$-sheet conformation, which suggested that D-Pro, the optical isomer of L-Pro, may further promote the formation of $\beta$-sheets; the propensity for the formation of $\beta$-hairpins and $\beta$-sheets may be influenced by the presence of alternating linked hydrophobic and hydrophilic amino acids and D-Pro, and this may play an important role in the process of sterilization.

On the one hand, our previous studies found that $\beta$-hairpin-like and symmetric-end antimicrobial peptides demonstrated length-dependent antimicrobial activity and membrane-active mechanisms using the quantitative structure activity relationship (QSAR) analysis $[27,28]$. In this study, the longest of the engineered peptides, OIR3, IR3 and DIR3, each have 14 amino acid residues and exhibit high antimicrobial activity, while the shorter peptides, with the exception of OIR2 and DIR2, inhibit the growth of E. coli only slightly and demonstrate no antimicrobial activity against all detected bacteria (Table 2). However, GS, which has 10 amino acid residues, had high antimicrobial activity, which suggested that the length or size of the peptides was not a determinant of the antimicrobial activity [29]. On the other hand, recent studies have showed that cyclization was not essential for the antimicrobial activity of linear and cyclic antimicrobial lipopeptides in the Paenibacillus strain [30]; another study found that cyclic peptides do not demonstrate greater permeability than their linear counterparts [29]. However, other studies demonstrated that head-to-tail cyclic peptides had greater antimicrobial activity compared to their linear counterparts [31,32] due to the ability of a head-to-tail cyclic peptide to span the bilayer, facilitating the formation of an anion-selective pore and thereby enabling translocation across the bilayer; in contrast, a linear peptide failed to promote translocation [33]. In this study, the geometric mean of the MICs of the OIR3 peptide was six-fold lower than that of the linear peptide IR3, which indicated that the conformational ordering established upon macrocyclization was associated with an enhanced capacity to inhibit bacterial cell growth. Moreover, the ability of IR3 to adopt a $\beta$-hairpin or $\beta$-sheet conformation was diminished, likely due the fixed secondary structure produced as a result of the head-to-tail cyclization of the backbone of OIR3 and the presence of Pro that contained rigid $\beta$-turns. Previous study found that peptides that including D-form amino acids had higher antimicrobial activity against both Gram-positive and Gram-negative bacteria compared to their counterparts lacking D-form amino acids [34]. DIR3, which contained D-Pro, exhibited higher antimicrobial activity than IR3, which contained only L-Pro, and this may be attributed to the presence of $\beta$-hairpins in DIR3 within the simulated membrane environment. An earlier study showed that peptides containing D-type proline displayed a higher affinity for $S$. aureus peptidoglycans and E. coli lipopolysaccharides than did those containing L-Pro [34], which suggested that specific interactions between D-form peptides and components of the bacterial cell wall may contribute to elevated antimicrobial activity.

The high cytotoxicity of peptide-based biomaterials towards mammalian cells is a major limitation for the development of AMPs as therapeutics. GS not only has great antimicrobial activity, but it is also highly toxic towards mammalian cells, which is attributed to its amphiphilic structure that causes it to lack selectively in its affinity for cellular membranes [35]. In this study, OIR3, IR3 and DIR3, which each have three IR repeating units, demonstrated no hemolytic activity towards erythrocytes (Table 1) and only weak toxicity towards RAW264.7 cells (Figure 2B), while GS had high toxicity towards mammalian cells, similar to that found previously, suggesting that the simplified, engineered active peptides had a great selectivity for negatively charged bacterial membranes versus zwitterionic mammalian cell membranes. These results demonstrated that the toxicity of AMPs in this system had only a weak relationship with cyclization, linearization and the presence of D-amino acid modification. High hydrophobicity can boost a peptide's antimicrobial potency, but to some extent it may also induce lysing of both bacteria and human cells, regardless of the degree of membrane damage [36]. GS has two Val (4.1) residues and two Leu residues (9.7), and one Phe (10) that have high hydrophobicity values according to by CCS scale [37] and that are strongly correlated with its greater cytotoxicity. 
Additionally, two molecules of Ornithine (Orn) with 2 net positive charges caused GS to be poorly amphiphilic. The engineered peptides OIR3, IR3 and DIR3 exhibit greater amphiphilicity, each having 6 net positive charges and 6 hydrophobic residues. Thus, an optimum hydrophobicity-amphiphilicity equilibrium has been suggested for use in the design of rational amphipathicity in peptides [38]. We further determined the cell selectivity of the amphiphiles by calculating their selectivity indexes (SI), which are a measure of the relative safety of the drugs. The cyclic peptide OIR3 had the highest selectivity index, which suggested it had the greatest cell selectivity. The novel finding of this work is that head-to-tail cyclization utilizing the template peptide sequence (IR) $)_{3} \mathrm{P}(\mathrm{IR})_{3} \mathrm{P}(n=1,2$ and 3$)$ produced peptides that had pronounced antimicrobial activity and selectivity enhancing effects.

In addition to the cellular selectivity of antimicrobial peptides, another important challenge for their pharmaceutical development is their stability in the presence of salt ions and serum. Salt ions affect the antimicrobial activity of peptides by interfering with electrostatic interactions and triggering competition in binding between cations and peptides [39]. A previous study demonstrated that the presence of salts would alter electrostatic effects and prohibit cationic peptides from attaching to bacteria, leading to reduced antimicrobial activity [7]. In this study, as shown in Table 3, the presence of $\mathrm{Na}^{+}$and $\mathrm{Ca}^{2+}$ slightly compromised the antibacterial actions of peptides against Gram-positive and Gram-negative bacteria, and this may be attributed to weakened electrostatic interactions. The most interesting result, however, was that IR3 had a remarkable ability to resist the effects of salt and demonstrated increased antimicrobial activity against all tested bacteria in high salt conditions. Our previous study showed that the antimicrobial activity of the symmetric-end linear peptide IR2 was increased under high salt conditions, and this may be due to facilitation of the binding of AMPs to bacterial membranes by a relatively low concentration of divalent cations [28]. In this study, the linear peptide IR3 had a more flexible skeletal structure due to it not being restrained by cyclization, which caused it to be more susceptible to salt ions compared to the cyclic peptide OIR3. In addition, OIR3 and DIR3 retained relatively high antimicrobial activity after treatment with serum, suggesting that cyclization and D-Pro modification can increase the stability of peptides in the serum environment.

Overall, the proposed mechanism for the antimicrobial activities of cationic AMPs is the perturbation and destruction of the bacteria membrane via selectively binding cationic peptides to negatively charged components (LPS) exposed within the bacterial membrane via electrostatic interactions; upon reaching a certain concentration threshold, the peptides are then inserted into the bilayer core, where they disrupt lipid packing and create transient pores/ion channels that allow leakage of cellular content across the membrane [40]. LPS, which is an endotoxin, is found at the surface of the outer membrane of Gram-negative bacteria and can regulate the membrane insertion and antibacterial activities of AMPs, depending upon their LPS binding and neutralizing ability [41]. In this study, LPS binding affinities and the SPR assay (Figure 3) demonstrate that OIR3 had a greater endotoxin neutralization potency than IR3, DIR3 and GS. Previous studies showed that, compared to that of their linear counterparts, the constrained backbone of cyclic peptides enhanced their cell permeability [42]. The engineered cyclic peptide OIR3 possessed a higher net positive charge (from six Arg residues) than GS (from two Orn residues), and the bidentate characteristic of the Arg guanidino group is considered to increase binding to the bacterial membrane [43,44]; thus, it is not difficult to infer that OIR3 had greater anti-LPS activity than GS.

The above results are further supported by the fact that OIR3 demonstrates greater outer membrane permeability than IR3, DIR3 and GS at low concentrations $(<8 \mu \mathrm{M})$, in a concentration-dependent manner. The outer membrane of Gram-negative bacteria is regarded as a major barrier that blocks the translocation of antimicrobial peptides across bacteria membranes [45]. Our results suggested that the large surface area and the reduced conformational flexibility of OIR3 might facilitate its outer membrane permeability (Figure 4). While peptide aggregation increased with increasing peptide concentration $(\geq 8 \mu \mathrm{M})$, GS was able to achieve higher outer membrane permeability, which may due to the larger proportion of its hydrophobic amino group that is inserted into the outer membrane. Permeabilization and depolarization of the $E$. coli inner membrane were monitored via $\beta$-galactosidase activity using 
ONPG (Figure 5) and a membrane potential-sensitive fluorescent dye, diSC3-5 (Figure 6). Our data indicates that cyclic peptide OIR3 demonstrated a greater capacity to permeabilize the inner membrane at a concentration $>8 \mu \mathrm{M}$ than IR3, DIR3 and GS. All of the engineered peptides were able to depolarize the cytoplasmic membrane, indicating that the potential dissipation may be correlated with membrane permeability induced by the formation of ionic channels or transmembrane pores. Research had shown that cyclic peptides bind more strongly to negatively charged membranes than linear peptides. The cyclic peptide folds at the membrane interface and adopts a $\beta$-sheet structure characterized by two turns, which facilitates its deeper penetration into the bilayer while the linear peptide essentially remains at the surface [46]. Using fluorescence-assisted cell sorting (FACS), the membrane integrity was analyzed and it was further confirmed that OIR3 exhibited an advantage in membrane permeability at 1× MIC (Figure 7). Our SEM (Figure 8) and TEM (Figure 9) studies further showed that OIR3 exerts its bactericidal activity through the destruction of cell membranes via the formation of membrane pores, leakage of the cytosol and eventually lysing of the entire cell [47].

The bacterial flagellum on the surface of Gram-negative bacterial species is primarily a motility organelle that enables motility and chemotaxis, which, in the host, are crucial for the infection of many pathogenic bacteria that must cross the mucosal barrier before accessing the intestinal cells [48]. The bacterial flagellum is driven by flagella motor (a molecular rotary motor) located at the base of the flagella close to the intima of bacterial cells and facing the cytoplasm [49]. In a solid medium containing $0.3 \%$ agarose, antimicrobial peptides OIR3, IR3 and DIR3 were able to inhibit bacterial swimming motility, especially at concentrations greater than $4 \mu \mathrm{M}$ (Figure 10), while GS was unable to inhibit bacterial swimming motility at all tested concentrations. A previous study showed that the motility and the ability of Salmonella enterica serovar Typhimurium to invade epithelial cells could be inhibited by an IgA monoclonal antibody that bound to the outermost $\mathrm{O}$ antigen of the lipopolysaccharide (LPS) [50], which the major constituent of the outer leaflet of the bacterial outer membrane. In this study, an endotoxin neutralization assay (Figure 3) showed that the cyclic peptide OIR3 had a slightly greater binding affinity for LPS from E. coli 25,922 than IR3, DIR3 and the cyclic peptide GS, which suggested that OIR3 may also bind to the O antigen of LPS and act in an antibody-like fashion to inhibit bacterial swimming motility.

The most highly anticipated finding related to the engineered peptides is the immunogenicity produced by the cyclic peptide OIR3 in host cells. Studies have showed that lipopolysaccharides elicit strong inflammatory responses by inducing the overexpression of Toll-like Receptor-4 (TLR4), IKB phosphorylation and degradation, and NF- $\mathrm{kB}$ activation, thereby leading to downstream release of early proinflammatory factors such as TNF- $\alpha$ [38]. Antimicrobial peptide AWRK6 significantly inhibited LPS-induced inflammatory responses by blocking the activation of the TLR4/NF- $\mathrm{KB}$ pathway [51]. The proinflammatory cytokine TNF- $\alpha$ can cause tissue injury and septic shock, which can lead to pathological conditions such as bacterial and viral infections, autoimmune conditions and inflammatory diseases [52]. Here, the antimicrobial and anti-inflammatory activities of cyclic peptides OIR3 and GS were evaluated by measuring the expression of inflammatory cytokine TNF- $\alpha$. Upon stimulation of RAW264.7 macrophages with $100 \mathrm{ng} / \mathrm{mL}$ LPS in the presence of cyclic peptide OIR3, we found that OIR3 can effectively inhibit TNF- $\alpha$ release in a dosage-dependent method (Figure 11). These results confirmed that the cyclic antimicrobial peptide OIR3 had anti-inflammatory characteristic that inhibit the production of proinflammatory factors.

To further evaluate the anti-inflammatory properties of the engineered peptide OIR3, we also demonstrated the beneficial effects of OIR3 in oxazolone-induced skin inflammation in mice (Figure 12). The cyclic peptide OIR3 potently suppressed oxazolone-induced ear swelling, as demonstrated by its ability to significantly decrease ear thickness and ear punch weight. Histopathological evaluation further confirmed that OIR3 could significantly improve edema of the ear, while GS was not as effective in treating inflammation in the ears of mice. In addition, the cyclic peptide OIR3 improved chronic inflammatory skin disorders, most likely via the inhibition of TNF- $\alpha$, IL- $1 \beta$ and IL- 6 mRNA expression (Figure 13). As previously stated, a cyclic peptide was effective at reducing inflammation in 
a mouse model of acute colitis, suggesting that the use of cyclic peptides as structural backbones offers a promising approach for the treatment of inflammatory bowel diseases and, potentially, other chronic inflammatory conditions [53]. A recent review reported that host defense peptides can orchestrate host immunomodulatory functions and are able to serve as a bridge between the innate and adaptive immune responses during skin inflammation and infection [54]. Cyclic peptide OIR3 had greater ability to reduce skin inflammation, which may be attributed to its greater abilities to bind and neutralize LPS and inhibit proinflammatory cytokine release, thereby blocking the pathways that induce the expression of inflammatory factors.

\section{Materials and Methods}

\subsection{Materials}

The murine macrophage cell line RAW264.7 was purchased from the cell bank of the Chinese Academy of Sciences, SIBS (Shanghai, China). Mueller Hilton broth (MHB) was obtained from AoBoX (Shanghai, China). Phosphate-buffered saline (PBS) solution was purchased from Solarbio (Beijing, China) and used following dilution to $10 \mathrm{mM}$ (pH 7.4); sodium dodecyl sulfate (SDS) and trifluoroethyl alcohol (TFE) were also purchased from Solarbio (Beijing, China). Human red blood cells (hRBCs) were obtained from healthy blood donors. RPMI 1640 and fetal bovine serum (FBS) were purchased from Invitrogen (Carlsbad, CA, USA). Glucose and lactose (analytical grade) were purchased from Zhiyuan (Tianjin, China). Sodium chloride, potassium chloride, ammonium chloride, zinc chloride, magnesium chloride and ferric chloride were all of analytical grade and purchased from Kermel (Tianjin, China). 3-(4, 5-demethylthiazol-2-yl)-2,5-diphenyltetrazolium bromide (MTT) and dimethyl sulfoxide (DMSO) were purchased from Sigma-Aldrich (Shanghai, China) and Amresco (Wayne, PA, USA), respectively. TritonX-100, propidium iodide (PI), Polymyxin B, o-nitrophenyl-b-D-galactopyranoside (ONPG), N-phenyl-1-napthylamine (NPN), 3.3'-depropylthiadicarbocyanine iodide (DiSC3-5), HEPES, ethanol (analytical grade, 99\%), acetone (analytical grade, 99\%), lipopolysaccharide (LPS, derived from E. coli 055: B5) and BODIPY-TR-cadaverine were all obtained from Sigma (Shanghai, China). Ethanol, acetone, tertiary butanol and glutaraldehyde were all analytical grade (Sigma-Aldrich, Shanghai, China). The Griess reagent system was purchased from Promega (Madison, WI, USA). A mouse TNF- $\alpha$ ELISA kit was purchased from Boster (EK0527, Wuhan, China). Acetate buffer (pH 5.5), M-MLV reverse transcriptase (Takara, Dalian, China), 4-Ethoxymethylene-2-phenyloxazone (oxazolone) and dexamethasone were purchased from Sigma (Shanghai, China).

\subsection{Bacterial Strains}

The test strains, including Gram-negative E. coli ATCC25922, E. coli ATCC 1005, S. typhimurium C7731, P. aeruginosa ATCC 27853, S. Typhimurium 14028, Gram-positive S. aureus ATCC29213, S. aureus ATCC 25923, S. epidermidis ATCC 12228 and S. aureus 43300, were obtained from the School of Veterinary Medicine, Northeast Agricultural University (Harbin, China).

\subsection{Peptide Design and Sequence Analysis}

Head-to-tail cyclic peptides, known as 'Cyclic Peptide type II', contain a cyclic backbone with $\mathrm{N}$ to C-terminal linkage [55]. In this study, the amphiphilic type II cyclic peptide was constructed according to the template sequence (IR) ${ }_{\mathrm{n}} \mathrm{P}(\mathrm{IR})_{\mathrm{n}} \mathrm{P}(n=1,2$ and 3$)$, and the repeat sequences (IR) $)_{\mathrm{n}}$ were composed of hydrophobic amino acid Ile (I) and hydrophilic amino acid Arg (R). The Ile and Arg were used based on our previous study that found that symmetric-end peptides with IR amino acid repeat sequences had the highest cell selectivity [28]. Arginine contains a guanidinium group, which has a pKa of 12.48 , and is therefore always protonated and positively charged during physiological conditions. Arg residues can participate in cation- $\pi$ interactions, thus potentially enhancing peptide-membrane interactions. Hydrophobic amino acid Ile, which is aliphatic, has a high hydrophobicity according to CCS [37]. Pro, a heterocyclic amino acid, has a side chain with a cyclic structure that locks the $\varphi$ 
angle at approximately $-65^{\circ} \mathrm{C}[56]$ and this often aids in the formation of rigid $\beta$-turns due to the lack of a hydrogen-bonding donor group and steric hindrance that prevents hydrogen bonding to adjacent residues. These head-to-tail cyclic peptides adopt a full $\beta$-sheet structure where the Ile and Arg residues align to form two antiparallel $\beta$-strands, while Ile and Pro form type II' $\beta$-turns. This structure is stabilized by inter-strand hydrogen bonds and thus folds into a fairly rigid amphipathic structure. In addition, to detect the effect of cyclization and modification of the conformation on biological activity, these cyclic peptides were decyclized to obtain linear counterpart peptides IR1, IR2 and IR3. Additionally, we substituted L-Pro with D-Pro in IR1, IR2 and IR3 to create peptides DIR1, DIR2 and DIR3, respectively.

The primary physicochemical parameters and sequences of the engineered peptides were determined using bioinformatics websites, including ProtParam (ExPASy Proteomics Server: http: //www.expasy.org/tools/protparam.html) and the antimicrobial peptide database (http://aps.unmc.edu/ $\mathrm{AP} /$ main.php).

\subsection{Synthesis and Characterization of Peptides}

The engineered peptides were synthesized and purified by the SciLight Biotechnology, LLC company (Beijing, China) using solid-phase methods utilizing N-9-fluorenylmethyloxycarbonyl (Fmoc) chemistry. The molecular weight of the peptides was confirmed using MALDI-TOF MS (Bruker Daltonics Inc., Carlsbad, CA, USA) with $\alpha$-cyano-4-hydroxycinnamic acid as the matrix. The purity of the peptides was determined to be more than $95 \%$ using high-performance liquid chromatography (HPLC). To prevent the degradation of the peptides, each peptide was dissolved in DI water at a concentration of $2.56 \mathrm{mM}$ and stored at $-20^{\circ} \mathrm{C}$.

\subsection{Circular Dichroism (CD) Spectroscopy}

Circular dichroism spectroscopy was used to investigate conformational changes induced by the membrane environment [57]. The antimicrobial peptides (AMPs) were dissolved in a $10 \mathrm{mM}$ phosphate buffer solution (PBS; pH 7.4) containing 50\% TFE and $30 \mathrm{mM}$ SDS in order to prepare a solution with a certain concentration of the peptide. The circular dichroism spectrometer quartz cell had a light path of $0.1 \mathrm{~cm}$, and the scanning wavelength was $190-250 \mathrm{~nm}$, the resolution was $0.5 \mathrm{~nm}$, the bandwidth (BW) was $1.0 \mathrm{~nm}$ and the scanning speed was $50 \mathrm{~nm} / \mathrm{min}$. The measurements were carried out at room temperature. The circular dichroism was expressed in terms of the average molar ellipticity, in degrees per centimeter/mole (degree. $\left.\mathrm{cm}^{2} \cdot \mathrm{dmol}^{-1}\right)$.

The acquired CD signal spectra were then converted to the mean residue ellipticity using the following equation:

$$
\theta_{\mathrm{M}}=\frac{\theta_{o b s} \cdot 1000}{c \cdot l \cdot n}
$$

where $\theta_{M}$ is the mean residue ellipticity (degree $\left.\cdot \mathrm{cm}^{2} \cdot \mathrm{dmol}^{-1}\right), \theta_{\text {obs }}$ is the observed ellipticity corrected for the buffer at a given wavelength (mdeg), $c$ is the peptide concentration $(\mathrm{mM}), 1$ is the path length $(\mathrm{mm})$ and $\mathrm{n}$ is the number of amino acids.

\subsection{Antimicrobial Assays}

Briefly, the bacteria were incubated overnight at $37^{\circ} \mathrm{C}$ with constant shaking at $220 \mathrm{rpm}$, then were transferred to new MH broth (MHB) medium until they reached the logarithmic phase of growth. The bacteria were then diluted to $10^{5}(\mathrm{CFU}) / \mathrm{mL}$ in MHB. The peptides were dissolved and diluted in $0.01 \%$ acetic acid and $0.2 \%$ bovine serum albumin (BSA) at various concentrations $(0.5-128 \mu \mathrm{M})$ in each well of sterile 96 -well plates and incubated for $20 \mathrm{~h}$ at $37^{\circ} \mathrm{C}$. The MIC was determined as the lowest concentration of the peptide that resulted in no bacterial growth, and spectrophotometrically determined by measuring the optical density (OD) at $492 \mathrm{~nm}$ at the end of a $20 \mathrm{~h}$ incubation. The test was repeated three times. 


\subsection{Stability Assays}

The salt ion sensitivity of the peptide was analyzed using the same method used to determine MIC. Determination in E. coli ATCC 25,922 and S. aureus ATCC 29,213 was conducted at various concentrations of physiological salt ions that simulated in vitro animal body salt concentrations, such as $4.5 \mathrm{mM} \mathrm{KCl}, 150 \mathrm{mM} \mathrm{NaCl}, 6 \mu \mathrm{M} \mathrm{NH}_{4} \mathrm{Cl}, 1 \mathrm{mM} \mathrm{MgCl} 2,8 \mu \mathrm{M} \mathrm{ZnCl}_{2}$ and $4 \mu \mathrm{M} \mathrm{FeCl}_{3}$. The stability of the peptide in $50 \%$ and $25 \%$ human inactivated serum was determined using the same method. The tests were repeated three times.

\subsection{Hemolysis Assays}

The hemolytic activity of the peptides is determined by measuring the amount of hemoglobin released during the lysis of human erythrocytes at different concentrations of AMPs [58]. Briefly, fresh, healthy human red blood cells (hRBCs) were collected and then washed three times with phosphate-buffered saline (PBS) buffer ( $\mathrm{pH} 7.2$ ) and centrifuged at $1000 \times g$ for $5 \mathrm{~min}$. Each $50 \mu \mathrm{L}$ sample of hRBCs was incubated with $50 \mu \mathrm{L}$ of the respective peptide dissolved in PBS in a well of a 96-well plate for $1 \mathrm{~h}$ at $37^{\circ} \mathrm{C}$. After incubation, the samples were centrifuged at $1000 \times g$ for $5 \mathrm{~min}$ and the supernatants $(50 \mu \mathrm{L})$ were transferred to a new 96 -well microplate. The release of hemoglobin was measured by monitoring the OD at $570 \mathrm{~nm}$ (Tecan, Salzburg, Austria). Negative (hRBCs without AMP treatment) and positive (hRBCs treated with $0.1 \%$ TritonX-100) controls were used. The concentration of peptide that caused $5 \%$ hemolysis was considered the minimal hemolysis concentration (MHC). The test was repeated three times. The percent hemolysis was calculated using the following formula:

$$
\text { Percent hemolysis }=\frac{\mathrm{A}-A_{0}}{A_{t}-A_{0}} \times 100 \%
$$

$\mathrm{A}_{0}$ and $\mathrm{A}_{\mathrm{t}}$ represent $0 \%$ and $100 \%$ hemolysis as measured in $10 \mathrm{mM}$ PBS and $0.2 \%$ Triton $\mathrm{X}-100$, respectively.

\subsection{Cytotoxicity Assay}

The MTT (3-[4, 5 dimethylthiozol-2-yl]-2,5-diphenyltetrazolium bromide) assay was conducted according to a previously reported MTT colorimetric method [59], and is used as a cell proliferation and cell viability assay. Mouse macrophage RAW264.7 cell lines stored in liquid nitrogen were recovered and cultured in a fully humidified atmosphere with $95 \%$ air and $5 \% \mathrm{CO}_{2}$ at $37^{\circ} \mathrm{C}$. The cells were then diluted, added to 96 -well plates at a final concentration of $2 \times 10^{5}$ cells/well, and cultured in RPMI 1640 medium at $37^{\circ} \mathrm{C}$ overnight. The next day, peptides were added to the cell cultures at final concentrations of $0.5-128 \mu \mathrm{M}$, and untreated cell cultures serving as controls were cultured for 20-24 h in the same conditions. Cell cultures were subsequently incubated with MTT ( $50 \mu \mathrm{L}, 0.5 \mathrm{mg} / \mathrm{mL}$ ) for $4 \mathrm{~h}$ at $37^{\circ} \mathrm{C}$. The cell cultures were then centrifuged at $1000 \times g$ for $5 \mathrm{~min}$, and the supernatants were discarded. $150 \mu \mathrm{L}$ of DMSO was added to dissolve the formazan crystals, and the OD was measured using a microplate reader (Tecan GENios F129004, Salzburg, Austria) at $570 \mathrm{~nm}$. Testing was repeated three times.

\subsection{Swimming Motility Assays}

Since E. coli ATCC 25,922 cell walls have flagella, their swimming motility can be measured in LB medium containing $0.3 \%$ agar [60]. E. coli ATCC 25,922 bacteria were incubated overnight at $37^{\circ} \mathrm{C}$ in a shaker until the $\mathrm{OD}_{600}=1.0$, then inoculated into $0.3 \%$ agar medium containing $1 \mu \mathrm{M}, 2 \mu \mathrm{M}, 4 \mu \mathrm{M}$ or $8 \mu \mathrm{M}$ of antimicrobial peptide and incubated again overnight at $37^{\circ} \mathrm{C}$. The swimming motility for each was then measured; each experiment was repeated three times. 


\subsection{Binding Affinities to LPS}

The BODIPY-TR-cadaverine (BC) displacement assay was previously used to quantify the binding affinities of test compounds to LPS [61]. The fluorescent dye BC is quenched by binding to LPS, causing its fluorescence to disappear. When the antimicrobial peptide is added, if the binding of the peptide to LPS is stronger, BODIPY-TR-cadaverine will be released and the fluorescence restored. Briefly, in a 96-well plate, an equal volume with a different concentration $(0.5-64 \mu \mathrm{M})$ of peptide was added to a mixture $(100 \mu \mathrm{L})$ of LPS $(25 \mu \mathrm{g} / \mathrm{mL})$ and BC $(2.5 \mu \mathrm{g} / \mathrm{mL})$ in Tris buffer $(\mathrm{pH} 7.4)$, and the background fluorescence was recorded (excitation wavelength $580 \mathrm{~nm}$, emission wavelength $620 \mathrm{~nm}$ ). The changes in fluorescence were recorded using a Tecan Infinite M200 PRO (Tecan, San Jose, CA, USA); polymyxin $\mathrm{B}$ was used as a positive control. Each test was performed independently, in triplicate.

\subsection{Surface Plasmon Resonance (SPR) Experiments}

Surface plasmon resonance (SPR) is a method commonly used to study protein-protein interactions. The main advantage of SPR is that it provides the ability to measure the binding affinities and association/dissociation kinetics of complexes in real time, in a label-free environment, and using relatively small quantities of materials [62]. Real-time binding interactions between peptides and LPS were measured by using the Biacore 3000 instrument (GE Healthcare, Waukesha, Wisconsin, USA). In $10 \mu \mathrm{g} / \mathrm{mL}$ sodium acetate buffer ( $\mathrm{pH}$ 5.5), the cyclic antimicrobial peptides OIR3, IR3, DIR3 and GS were diluted to an optimum fixed concentration of $25.6 \mu \mathrm{M}$, and then covalently immobilized on the CM5 sensor chip; nearly 1100 resonant units (RU) of the peptide were captured. All measurements were performed in $20 \mathrm{mM}$ Tris buffer (pH 7.4) containing $100 \mathrm{mM} \mathrm{NaCl}$. LPS in running buffer ( $20 \mathrm{mM}$ Tris, $100 \mathrm{mM} \mathrm{NaCl}, \mathrm{pH} 7.4$ ) was allowed to flow over the chip surface at concentrations of $3.125-50 \mu \mathrm{g} / \mathrm{mL}$ at a rate of $30 \mu \mathrm{L} / \mathrm{min}$. After each injection, the surface was reengineered using a solution containing $20 \mathrm{mM}$ Tris, $50 \mathrm{mM} \mathrm{NaOH}$ and $0.05 \%(w / v)$ SD. Each test was conducted three times independently.

\subsection{Outer Membrane Permeability Assay}

The effect of antimicrobial peptides on the outer leaflet of the cell membrane was examined using the extracellular membrane-sensitive fluorescent dye NPN and the antibiotic-sensitive mutant $E$. coli UB 1005. E. coli bacteria were incubated overnight and then transferred to fresh $\mathrm{MH}$ broth medium. The bacteria were cultured at $37^{\circ} \mathrm{C}$ with shaking at $200 \mathrm{rpm}$ for $3 \mathrm{~h}$ until the $\mathrm{OD}_{600}$ of the bacterial suspension reached 0.4; then they were centrifuged at $3000 \mathrm{rpm}$ for $3 \mathrm{~min}$ and the supernatant was discarded. After adding $5 \mathrm{mM} / \mathrm{L}$ HEPES buffer ( $\mathrm{pH}$ 7.4) that contained $5 \mathrm{mM}$ glucose, the bacteria were collected by centrifugation again. The same buffer was used to suspend bacteria to $\mathrm{OD}_{600} \mathrm{~nm}=0.4$; NPN was added to the bacterial suspension at a final concentration of $20 \mu \mathrm{M}$. The background fluorescence was measured (excitation $\lambda=350 \mathrm{~nm}$, emission $\lambda=420 \mathrm{~nm}$ ) with an F-4500 fluorescence spectrophotometer (Hitachi, Tokyo, Japan). A $2 \mathrm{~mL}$ volume of cell suspension was added to a $1 \mathrm{~cm}$ quartz cuvette and mixed with different final peptide concentrations. The fluorescence was recorded in terms of the time needed until there was no further increase in fluorescence after mixing several concentrations $(0.5-64 \mu \mathrm{M})$ of peptides. Polymyxin B was used as a positive control because of its strong outer membrane permeability. Values were converted to percent NPN uptake using the following equation:

$$
\% \text { NPN uptake }=\frac{F_{o b s}-F_{0}}{F_{100}-F_{0}} \times 100 \%
$$

where $\mathrm{F}_{\mathrm{obs}}$ is the observed fluorescence at a given peptide concentration, $\mathrm{F}_{0}$ is the initial fluorescence of NPN in E. coli UB1005 cells and $F_{100}$ is the fluorescence of NPN in UB1005 cells upon the addition of $10 \mu \mathrm{g} / \mathrm{mL}$ polymyxin $\mathrm{B}$, which had strong outer membrane permeability. 


\subsection{Inner Membrane Permeability Assay}

The change in intracellular $\beta$-galactosidase activity was measured by measuring intracellular $\beta$-galactosidase activity [63]. Briefly, E. coli UB1005 bacteria were inoculated into MHB containing 2\% lactose and cultured overnight. The cells were transferred to new MHB containing $2 \%$ lactose and allowed to grow to the logarithmic phase, and then were centrifuged and the bacterial precipitate was collected. The bacteria were resuspended in sterile PBS containing $1.5 \mathrm{mM}$ ONPG to adjust the bacterial concentration to $\mathrm{OD}_{600}=0.2$; after adding antimicrobial peptide, the absorbance was measured at $420 \mathrm{~nm}$, and the value was read every $2 \mathrm{~min}$. The determination time was $40 \mathrm{~min}$.

\subsection{Cytoplasmic Membrane Electrical Potential Measurement}

We used the cell membrane potential-sensitive fluorescent dye diSC3-5 and the antibiotic-sensitive mutant E. coli UB1005 to detect the effect of antimicrobial peptides on cell membrane depolarization [60]. Briefly, mid-logarithmic phase E. coli were washed with $5 \mathrm{mM}$ sodium HEPES buffer (pH 7.4) containing $20 \mathrm{mM}$ glucose and resuspended to an $\mathrm{OD}_{600}=0.05$ in the same buffer. The dye diSC $3-5$ was added to a final concentration of $0.4 \mu \mathrm{M}$ until a stable reduction of fluorescence was achieved (approximately $1 \mathrm{~h}$ ). To equilibrate the cytoplasmic and external $\mathrm{K}^{+}$concentrations, $\mathrm{KCl}$ was added to the cell suspension containing diSC $_{3}-5$ to a final concentration of $200 \mathrm{mM}$, and then incubated for $15 \mathrm{~min}$ at room temperature. Of bacterial liquid $2 \mathrm{~mL}$ was added to a 24 -well plate, and the peptides were added to achieve the desired concentrations (1/4× MIC, $1 / 2 \times \mathrm{MIC}, 1 \times \mathrm{MIC}, 2 \times \mathrm{MIC}$ and $4 \times \mathrm{MIC})$. The fluorescence was recorded using a Tecan Infinite M200 PRO (Tecan, USA) at an excitation wavelength of $622 \mathrm{~nm}$ and an emission wavelength of $670 \mathrm{~nm}$.

\subsection{Flow Cytometry}

Membrane integrity assay. Briefly, E. coli ATCC 25,922 were grown to mid logarithmic phase in MHB, washed three times with PBS and diluted to $10^{5} \mathrm{CFU} / \mathrm{mL}$. Different peptides concentrations $(1 / 2 \times$ MIC, $1 \times$ MIC and $2 \times$ MIC) were incubated with the bacterial suspension at a fixed PI concentration of $10 \mathrm{ug} / \mathrm{mL}$ for $30 \mathrm{~min}$ at $4{ }^{\circ} \mathrm{C}$, and followed by the removal of the unbound dye through washing with PBS. FACS flow cytometer (Becton-Dickinson, Franklin Lake, New Jersey, USA USA) was used to obtain the data with a laser excitation wavelength of $488 \mathrm{~nm}$.

\subsection{Scanning Electron Microscopy (SEM)}

E. coli ATCC 25,922 were cultured in MHB to mid-log phase and harvested by centrifugation at $3000 \times g$ for $5 \mathrm{~min}$. Cells pellets were washed twice with $10 \mathrm{mM} \mathrm{PBS}$ and resuspended to an $\mathrm{OD}_{600}=0.2$. Peptide treatment of the bacterial cells was performed at $37^{\circ} \mathrm{C}$ for $1 \mathrm{~h}$ at their respective $1 \times \mathrm{MIC}$. After incubation, the cells were washed with PBS then centrifuged at $3000 \times g$ for 5 min three times, and then fixed with $2.5 \%(w / v)$ glutaraldehyde at $4{ }^{\circ} \mathrm{C}$ overnight. The next day, the bacteria were washed twice with PBS and dehydrated using a graded ethanol series (50\%, 70\%, 90\% and 100\%) for 15 min each. The samples were then transferred to a mixture $(1: 1, v / v)$ of ethanol and tertiary butanol, then $100 \%$ tertiary butanol, for $20 \mathrm{~min}$ each time. After lyophilization and gold coating, the specimens were observed using a scanning electron microscope (Hitachi S-4800, Tokyo, Japan).

\subsection{Transmission Electron Microscopy (TEM)}

Bacterial sample preparation for TEM was conducted using the same method as that for SEM [64]. Bacterial cells were fixed with $2.5 \%$ glutaraldehyde at $4{ }^{\circ} \mathrm{C}$ overnight, washed twice in PBS, and fixed with $2 \%$ osmium tetroxide for $60 \mathrm{~min}$. They were then washed twice with PBS and dehydrated for 5 min each using a graded ethanol series (50\%,70\%, 90\% and 100\%), followed by 8 min each in 100\% ethanol and a mixture (1:1) of 100\% ethanol and acetone. The sample was then transferred into a 1:1 mixture of absolute epoxy and acetone resin for $35 \mathrm{~min}$, and then into pure epoxy resin for incubation 
overnight at a constant temperature. The specimens were then sectioned using an ultramicrotome, stained with uranyl acetate and lead citrate, and observed using a HITACHI H-7650 TEM.

\subsection{Determination of Inflammatory Factors}

LPS-activated inflammatory responses are always accompanied by the production of inflammatory cytokines, such as tumor necrosis factor-alpha (TNF- $\alpha$ ) [65]. Briefly, $2 \times 10^{5}$ cells/well RAW264.7 cells were plated in 96-well plates and stimulated with LPS $(100 \mathrm{ng} / \mathrm{mL})$ in the absence or presence of the peptides $(1-32 \mu \mathrm{M})$ for $18 \mathrm{~h}$ at $37^{\circ} \mathrm{C}$. The levels of TNF- $\alpha$ were determined using an ELISA kit (Boster, Wuhan, China) in accordance with the manufacturer's instructions. TNF- $\alpha$ was measured by determining the absorbance at $540 \mathrm{~nm}$.

\subsection{Animal Experiments}

ICR mice (male, 4-6 weeks old, and 18-22 g) were obtained from the Experimental Animal Center of Harbin Medical University. All mice were reared in plastic cages with food and water under standard conditions and air filtration $\left(22 \pm 2{ }^{\circ} \mathrm{C}, 12 \mathrm{~h} \mathrm{light/dark}\right.$ cycles). The study was in accordance with the Local Guide for the Care and Use of Laboratory Animals of Harbin Medical University and used Committee of Northeast Agricultural University (NEAU-(2011)-9).

\subsection{Allergic Dermatitis Mode}

4-Ethoxymethylene-2-phenyl-2-oxazolin-5-one (oxazolone, OXA) was used to induce ear edema in mice [66]. Briefly, all of the experimental mice were randomly divided into eight groups $(n=8): 1$ ) the positive control group (0.1\% dexamethasone) [67]; 2 ) the negative control group (without peptide) and $3-8)$ the treated groups $(0.5 \%, 1 \%$ or $2 \%$ w/v of either OIR3 or GS). The fur was clipped from each animal's abdomen the day before the experiment was conducted. On the day of the experiment (day 0), $50 \mathrm{ul} 3 \%$ oxazolone induction solution (prepared in a 5:1 ( $\mathrm{v} / \mathrm{v})$ mixture of acetone: corn oil carrier) was applied to all mice as a single topical application to the shaved abdomen. After 5 days, $50 \mu \mathrm{L}$ of $1 \%$ oxazolone challenge solution (prepared in acetone) was applied as a single topical application to the dorsal area of the right ear for $1 \mathrm{~h}$. Of the peptide solution, vehicle control or positive control (dexamethasone) solution $20 \mu \mathrm{L}$ was applied topically to the dorsal area of the right ear. The left ear was used as a control. $24 \mathrm{~h}$ later, the mice were euthanized by cervical dislocation under ether anesthesia, and two ear punches $(6 \mathrm{~mm}$, i.d.) were collected and weighed. The degree of edema and the increase in ear thickness were determined by the increase in the weight and thickness of the right ear punch when compared with that of the left ear. All animal experiments were performed in accordance with the guidelines for the care and use of laboratory animals approved by the Institutional Animal Care and Use Committee of Northeast Agricultural University (NEAU-(2011)-9).

$$
\text { Ear weight increase } \%=\frac{[\text { Right ear weight }(\mathrm{mg})-\text { Left ear weight }(\mathrm{mg})]}{\text { Left ear weight }(\mathrm{mg})} \times 100 \%
$$

$$
\text { Increase of the ear thickness } \%=\frac{\text { Right ear thickness }(\mathrm{mm})-\text { Left ear thinkcess }(\mathrm{mm})}{\text { Left ear thickness }} \times 100 \%
$$

\subsection{Hematoxylin and Eosin (HE) Staining}

Ear tissues were collected and fixed in $10 \%$ formaldehyde for at least $24 \mathrm{~h}$ at room temperature. After dehydration in different concentrations of alcohol, tissues were embedded in paraffin and then sliced. H\&E staining was performed, and sections were observed under a light microscope (Olympus, Glasgow, UK) [68]. 


\subsection{Determination of Inflammatory Factors}

Mouse ear tissues were ground in liquid nitrogen and $1 \mathrm{~mL}$ of Trizol was added. The total RNA content in each group of ears was extracted using the conventional Trizol method. qRT-PCR was used to measure the mRNA level of inflammatory cytokines TNF- $\alpha$, IL- 6 and IL- $1 \beta$ in mouse ear tissues. One microgram total of RNA was reverse transcribed using M-MLV reverse transcriptase (Takara, Japan). qRT-PCR was performed using a SYBR Green Mix kit (Takara, Japan) with a 7500 Real-Time PCR system according to the manufacturer's instructions. The mRNA expression levels were normalized to $\beta$-actin using the $\left(2^{-\Delta \Delta C t}\right)$ method. The gene expression was normalized to the corresponding mGAPDH level. The main primers used for qRT-PCR in this study are shown in Table 4 . Each test was repeated at least three times, with three replicates.

\subsection{Statistical Analysis}

Data were analyzed by ANOVA using Graph Pad prism 6.2 software (San Diego, California, USA). Quantitative data are presented as the mean \pm standard deviation. $p<0.05$ was considered to connote statistical significance

\section{Conclusions}

A series of antimicrobial peptides utilizing different types secondary structures, including cyclic, linear, and L-/D-amino acid-modified structures, were designed based on the template (IR $)_{n} \mathrm{P}(\mathrm{IR})_{\mathrm{n}} \mathrm{P}$ ( $n=1,2$ and 3) including isoleucine, arginine and proline. In deionized water or a membrane mimetic solution, different secondary structures utilizing cyclization, linearization and L-/D-amino acid modifications exerted different structural transformations, and the most potentially amphiphilic peptide OIR3 exhibited a $\beta$-hairpin conformation in a membrane-mimetic environment, while in aqueous solution it formed a random coil. Results in vitro demonstrated that $(\mathrm{IR})_{3} \mathrm{P}(\mathrm{IR})_{3} \mathrm{P}$ had the greatest cell selectivity and antimicrobial activity against all measured bacteria, as well as lower erythrocyte cytotoxicity than linear peptide IR3, D-Pro peptide DIR3, or GS. Additionally, cyclic peptide OIR3 exhibited higher stability in various conditions than gramicidin S (GS), which may be attributed to its higher net positive charge and constrained backbone typical of cyclic peptides. The SPR and LPS-binding affinity binding assay indicated that OIR3 exhibited significant endotoxin binding and neutralizing capabilities. In addition, fluorescence spectroscopy, flow cytometry and electron microscopy all showed that OIR3 killed bacterial cells by destroying their cell membranes via cell lysis and the leakage of cytoplasm. LPS-induced inflammation in RAW264.7 cells was used to demonstrate that OIR3 possessed the ability to inhibit the production of pro-inflammatory factor TNF- $\alpha$. Further evaluation of its anti-inflammatory abilities in vivo revealed that OIR3 exhibited therapeutic effects by inhibiting oxazolone-induced skin inflammation via inhibition of TNF- $\alpha$, IL- $1 \beta$ and IL- 6 mRNA expression. In summary, the engineered head-to-tail cyclic peptide OIR3 had considerable potential as an ideal candidate for use as a clinical therapeutic to treat bacterial infections and skin inflammation.

Supplementary Materials: Supplementary materials can be found at http://www.mdpi.com/1422-0067/20/23/ 5904/s1.

Author Contributions: Conceptualization, N.D. and C.W.; methodology, C.W.; software, X.L.; validation, N.D. and Y.G.; formal analysis, X.L.; investigation, X.L.; resources, Y.G.; data curation, C.W.; writing-original draft preparation, N.D. and C.W.; writing-review and editing, N.D. and Y.G.; visualization, X.L.; supervision, Y.G. and N.D.; project administration, Y.G.; funding acquisition, Y.G. and N.D.

Funding: This work was financially supported by State Key Laboratory of Animal Nutrition, the National Natural Science Foundation of China (Grant No. 31972580 and 31501914), the Heilongjiang Province Natural Science Foundation (LH2019C023).

Conflicts of Interest: The authors declare no conflict of interest. 


\section{Abbreviations}

$\begin{array}{ll}\text { AMPs } & \text { antimicrobial peptides } \\ \text { CD } & \text { circular dichroism } \\ \text { DMSO } & \text { dimethyl sulfoxide } \\ \text { EDTA } & \text { ethylenediaminetetraacetic acid } \\ \text { FACS } & \text { fluorescence-assisted cell sorting } \\ \text { FBS } & \text { fetal bovine serum } \\ \text { hRBCs } & \text { human red blood cells } \\ \text { LPS } & \text { lipopolysaccharides } \\ \text { MHB } & \text { Mueller-Hinton broth } \\ \text { MIC } & \text { minimum inhibitory concentration } \\ \text { MTT } & \text { 3-(4,5-dimethylthiozol-2-yl)-2,5-diphenyltetrazolium bromide } \\ \text { NF-kB } & \text { nuclear factor-kB } \\ \text { NO } & \text { nitric oxide } \\ \text { NPN } & \text { N-phenyl-1-naphthylamine } \\ \text { OD } & \text { optical density } \\ \text { PI } & \text { propidium iodide } \\ \text { qRT-PCR } & \text { quantitative real-time PCR } \\ \text { SDS } & \text { sodium dodecyl sulfate } \\ \text { SEM } & \text { scanning electronic microscopy } \\ \text { TFE } & \text { trifluoroethyl alcohol } \\ \text { TLR4 } & \text { Toll-like receptor-4 } \\ \text { DXM } & \text { dexamethasone } \\ & \end{array}$

\section{References}

1. Mi, G.; Shi, D.; Herchek, W.; Webster, T.J. Self-assembled arginine-rich peptides as effective antimicrobial agents. J. Biomed. Mater. Res. Part A 2017, 105, 1046-1054. [CrossRef]

2. Sun, H.; Hong, Y.; Xi, Y.; Zou, Y.; Gao, J.; Du, J. Synthesis, Self-Assembly and Biomedical Applications of Antimicrobial Peptide-Polymer Conjugates. Biomacromolecules 2018, 19, 1701-1720. [CrossRef]

3. Pérez-Peinado, C.; Dias, S.A.; Domingues, M.M.; Benfield, A.H.; Freire, J.M.; Rádis-Baptista, G.; Gaspar, D.; Marb, C.; Craik, D.J.; Henriques, S.T. Mechanisms of bacterial membrane permeabilization by crotalicidin (Ctn) and its fragment Ctn(15-34), antimicrobial peptides from rattlesnake venom. J. Biol. Chem. 2018, 293, 1536. [CrossRef]

4. Wang, J.; Dou, X.; Song, J.; Lyu, Y.; Zhu, X.; Xu, L.; Li, W.; Shan, A. Antimicrobial peptides: Promising alternatives in the post feeding antibiotic era. Med. Res. Rev. 2019, 39, 831-859. [CrossRef]

5. Tajbakhsh, M.; Karimi, A.; Tohidpour, A.; Abbasi, N.; Fallah, F.; Akhavan, M.M. The antimicrobial potential of a new derivative of cathelicidin from Bungarus fasciatus against methicillin-resistant Staphylococcus aureus. J. Microbiol. 2018, 56, 128-137. [CrossRef]

6. Yu, K.; Lo, J.C.Y.; Yan, M.; Yang, X.; Brooks, D.E.; Hancock, R.E.W.; Lange, D.; Kizhakkedathu, J.N. Anti-adhesive antimicrobial peptide coating prevents catheter associated infection in a mouse urinary infection model. Biomaterials 2017, 116, 69. [CrossRef]

7. Ma, Z.; Wei, D.; Yan, P.; Zhu, X.; Shan, A.; Bi, Z. Characterization of cell selectivity, physiological stability and endotoxin neutralization capabilities of $\alpha$-helix-based peptide amphiphiles. Biomaterials 2015, 52, 517-530. [CrossRef]

8. Zorzi, A.; Deyle, K.; Heinis, C. Cyclic peptide therapeutics: Past, present and future. Curr. Opin. Chem. Biol. 2017, 38, 24-29. [CrossRef] [PubMed]

9. Falanga, A.; Nigro, E.; De Biasi, M.G.; Daniele, A.; Morelli, G.; Galdiero, S.; Scudiero, O. Cyclic Peptides as Novel Therapeutic Microbicides: Engineering of Human Defensin Mimetics. Molecules 2017, 22, 1217. [CrossRef] [PubMed]

10. Lu, M.C.; Jiao, Q.; Liu, T.; Tan, S.J.; Jiang, Z.Y. Discovery of a head-to-tail cyclic peptide as the Keap1-Nrf2 protein-protein interaction inhibitor with high cell potency. Eur. J. Med. Chem. 2017, 143, 1578-1589. [CrossRef] [PubMed] 
11. Ong, Y.S.; Gao, L.; Kalesh, K.A.; Yu, Z.; Wang, J.; Liu, C.; Li, Y.; Sun, H.; Lee, S.S. Recent Advances in Synthesis and Identification of Cyclic Peptides for Bioapplications. Curr. Top. Med. Chem. 2017, 17, $2302-2318$. [CrossRef]

12. Frederick, B.A.; Helfrich, B.A.; Coldren, C.D.; Zheng, D.; Chan, D.; Jr, B.P.; Raben, D. Epithelial to mesenchymal transition predicts gefitinib resistance in cell lines of head and neck squamous cell carcinoma and non-small cell lung carcinoma. Mol. Cancer Ther. 2007, 6, 1683-1691. [CrossRef]

13. Gause, G.F.; Brazhnikova, M.G. Gramicidin S and its use in the Treatment of Infected Wounds. Nature 1944, 154, 703. [CrossRef]

14. Marina, R.; Hans André, E.B.; Nicolas Maré, V.; Marietjie, S.; Abré, D.B. Direct surfactin-gramicidin S antagonism supports detoxification in mixed producer cultures of Bacillus subtilis and Aneurinibacillus migulanus. Microbiology 2012, 158(Pt. 12), 3072-3082.

15. Shao, C.; Tian, H.; Wang, T.; Wang, T.; Chou, S.; Shan, A.; Cheng, B. Central $\beta$-turn increases the cell selectivity of imperfectly amphipathic $\alpha$-helical peptides. Acta Biomater. 2018, 69, 243-255. [CrossRef]

16. Song, Y.M.; Yang, S.T.; Lim, S.S.; Kim, Y.; Hahm, K.S.; Kim, J.I.; Shin, S.Y. Effects of L- or D-Pro incorporation into hydrophobic or hydrophilic helix face of amphipathic alpha-helical model peptide on structure and cell selectivity. Biochem. Biophys. Res. Commun. 2004, 314, 615-621. [CrossRef] [PubMed]

17. Kim, S.; Kim, S.S.; Lee, B.J. Correlation between the activities of alpha-helical antimicrobial peptides and hydrophobicities represented as RP HPLC retention times. Peptides 2005, 26, 2050-2056. [CrossRef] [PubMed]

18. Hu, H.; Kofoed, C.; Li, M.; Gonçalves, J.P.L.; Hansen, J.; Wolfram, M.; Hansen, A.K.; Hansen, C.H.F.; Diness, F.; Schoffelen, S.; et al. Computational Evolution of Threonine-Rich $\beta$-Hairpin Peptides Mimicking Specificity and Affinity of Antibodies. ACS Cent. Sci. 2019, 5, 259-269. [CrossRef] [PubMed]

19. Jobin, V.; Ramakrishnan, N. Antibacterial activity of human neutrophil defensin HNP-1 analogs without cysteines. Antimicrob. Agents Chemother. 2005, 49, 4561.

20. Gupta, V.K.; Kaushik, A.; Chauhan, D.S.; Ahirwar, R.K.; Sharma, S.; Bisht, D. Anti-mycobacterial activity of some medicinal plants used traditionally by tribes from Madhya Pradesh, India for treating tuberculosis related symptoms. J. Ethnopharmacol. 2018, 227, 113-120. [CrossRef]

21. Famuyide, I.M.; Aro, A.O.; Fasina, F.O.; Eloff, J.N.; McGaw, L.J. Antibacterial and antibiofilm activity of acetone leaf extracts of nine under-investigated south African Eugenia and Syzygium (Myrtaceae) species and their selectivity indices. BMC Complementary Altern. Med. 2019, 19, 141. [CrossRef]

22. Ryder, M.P.; Wu, X.; Mckelvey, G.R.; Mcguire, J.; Schilke, K.F. Binding interactions of bacterial lipopolysaccharide and the cationic amphiphilic peptides polymyxin B and WLBU2. Colloids Surf. B Biointerfaces 2014, 120, 81-87. [CrossRef]

23. Sarmishtha, D.; Hao, Z.; David, D.S.; Croniger, C.M.; Xiaoxia, L.; Stark, G.R. Erlotinib protects against LPS-induced endotoxicity because TLR4 needs EGFR to signal. Proc. Natl. Acad. Sci. USA 2015, 112, 9680.

24. Yuin, O.Z.; Junchi, C.; Yuan, H.; Kaijin, X.; Zhongkang, J.; Weimin, F.; Yan, Y.Y. Effect of stereochemistry, chain length and sequence pattern on antimicrobial properties of short synthetic $\beta$-sheet forming peptide amphiphiles. Biomaterials 2014, 35, 1315-1325.

25. Wang, J.; Chou, S.; Yang, Z.; Yang, Y.; Wang, Z.; Song, J.; Dou, X.; Shan, A. Combating drug-resistant fungi with novel imperfectly amphipathic palindromic peptides. J. Med. Chem. 2018, 61, 3889-3907. [CrossRef]

26. Ma, Q.Q.; Lv, Y.F.; Gu, Y.; Dong, N.; Li, D.S.; Shan, A.S. Rational design of cationic antimicrobial peptides by the tandem of leucine-rich repeat. Amino Acids 2013, 44, 1215-1224. [CrossRef]

27. Dong, N.; Ma, Q.; Shan, A.; Lv, Y.F.; Hu, W.; Gu, Y.; Li, Y. Strand length-dependent antimicrobial activity and membrane-active mechanism of arginine- and valine-rich $\beta$-hairpin-like antimicrobial peptides. Antimicrob. Agents Chemother. 2012, 56, 2994. [CrossRef]

28. Dong, N.; Zhu, X.; Chou, S.; Shan, A.; Li, W.; Jiang, J. Antimicrobial potency and selectivity of simplified symmetric-end peptides. Biomaterials 2014, 35, 8028-8039. [CrossRef] [PubMed]

29. Shin, M.K.; Hyun, Y.J.; Lee, J.H.; Lim, H.S. Comparison of Cell Permeability of Cyclic Peptoids and Linear Peptoids. ACS Comb. Sci. 2018, 20, 237-242. [CrossRef] [PubMed]

30. Huang, E.; Yang, X.; Zhang, L.; Moon, S.H.; Yousef, A.E. New Paenibacillus strain produces a family of linear and cyclic antimicrobial lipopeptides: Cyclization is not essential for their antimicrobial activity. FEMS Microbiol. Lett. 2017, 364. [CrossRef] [PubMed] 
31. Cirac, A.; Moiset, G.; Mika, J.; Koçer, A.; Salvador, P.; Poolman, B.; Marrink, S.; Sengupta, D. The Molecular Basis for Antimicrobial Activity of Pore-Forming CyclicPeptides. Biophys. J. 2011, 100, 2422-2431. [CrossRef] [PubMed]

32. Wessolowski, A.; Bienert, M.; Dathe, M. Antimicrobial activity of arginine- and tryptophan-rich hexapeptides: The effects of aromatic clusters, d-amino acid substitution and cyclization. Chem. Biol. Drug Des. 2010, 64, 159-169. [CrossRef] [PubMed]

33. Matsuzaki, K.; Yoneyama, S.; Fujii, N.; Miyajima, K.; Yamada, K.; Kirino, Y.; Anzai, K. Membrane permeabilization mechanisms of a cyclic antimicrobial peptide, tachyplesin I, and its linear analog. Biochemistry 1997, 36, 9799. [CrossRef] [PubMed]

34. Manabe, T.; Kawasaki, K. D-form KLKLLLLLKLK-NH2 peptide exerts higher antimicrobial properties than its L-form counterpart via an association with bacterial cell wall components. Sci. Rep. 2017, 7, 43384. [CrossRef] [PubMed]

35. Berditsch, M.; Trapp, M.; Afonin, S.; Weber, C.; Misiewicz, J.; Turkson, J.; Ulrich, A.S. Antimicrobial peptide gramicidin $\mathrm{S}$ is accumulated in granules of producer cells for storage of bacterial phosphagens. Sci. Rep. 2017, 7, 44324. [CrossRef]

36. Schmidtchen, A.; Pasupuleti, M.; Malmsten, M. Effect of hydrophobic modifications in antimicrobial peptides. Adv. Colloid Interface Sci. 2014, 205, 265-274. [CrossRef]

37. Cornette, J.L.; Cease, K.B.; Margalit, H.; Spouge, J.L.; Berzofsky, J.A.; Delisi, C. Hydrophobicity scales and computational techniques for detecting amphipathic structures in proteins. J. Mol. Biol. 1987, 195, 659-685. [CrossRef]

38. Ma, Z.; Yang, J.; Han, J.; Gao, L.; Liu, H.; Lu, Z.; Zhao, H.; Bie, X. Insights into the Antimicrobial Activity and Cytotoxicity of Engineered $\alpha$-Helical Peptide Amphiphiles. J. Med. Chem. 2016, 59, 10946-10962. [CrossRef]

39. Cheng, W.; Mingqiang, S.; Neelakshi, G.; Tolbert, W.D.; Fang, C.; Naixin, Z.; Ke, Y.; Aiping, W.; Yongping, S.; Tianmin, C. Design of a potent antibiotic peptide based on the active region of human defensin 5. J. Med. Chem. 2015, 58, 3083-3093.

40. Zhan, Y.O.; Wiradharma, N.; Yi, Y.Y. Strategies employed in the design and optimization of synthetic antimicrobial peptide amphiphiles with enhanced therapeutic potentials. Adv. Drug Deliv Rev. 2014, 78, $28-45$.

41. Taniguchi, M.; Ochiai, A.; Takahashi, K.; Nakamichi, S.I.; Nomoto, T.; Saitoh, E.; Kato, T.; Tanaka, T. Antimicrobial activity and mechanism of action of a novel cationic $\alpha$-helical octadecapeptide derived from $\alpha$-amylase of rice. Biopolymers 2015, 104, 73-83. [CrossRef] [PubMed]

42. Itoh, H.; Inoue, M. Comprehensive Structure-Activity Relationship Studies of Macrocyclic Natural Products Enabled by Their Total Syntheses. Chem. Rev. 2019, 119, 10002-10031. [CrossRef] [PubMed]

43. Cutrona, K.J.; Kaufman, B.A.; Figueroa, D.M.; Elmore, D.E. Role of Arginine and Lysine in the Antimicrobial Mechanism of Histone-derived Antimicrobial Peptides. FEBS Lett. 2016, 589, 3915-3920. [CrossRef] [PubMed]

44. Li, J.; Koh, J.J.; Liu, S.; Lakshminarayanan, R.; Verma, C.S.; Beuerman, R.W. Membrane Active Antimicrobial Peptides: Translating Mechanistic Insights to Design. Front. Neurosci. 2017, 11, 73. [CrossRef]

45. Niv, P.; Yechiel, S. A molecular mechanism for lipopolysaccharide protection of Gram-negative bacteria from antimicrobial peptides. J. Biol. Chem. 2005, 280, 10378-10387.

46. Mika, J.T.; Moiset, G.; Cirac, A.D.; Feliu, L.; Bardají, E.; Planas, M.; Sengupta, D.; Marrink, S.J.; Poolman, B. Structural basis for the enhanced activity of cyclic antimicrobial peptides: The case of BPC194. Biochim. Biophys. Acta 2011, 1808, 2197-2205. [CrossRef]

47. Shao, C.; Li, W.; Tan, P.; Shan, A.; Dou, X.; Ma, D.; Liu, C. Symmetrical Modification of Minimized Dermaseptins to Extend the Spectrum of Antimicrobials with Endotoxin Neutralization Potency. Int. J. Mol. Sci. 2019, 20, 1417. [CrossRef]

48. Pedersen, R.M.; Grønnemose, R.B.; Stærk, K.; Asferg, C.A.; Andersen, T.B.; Kolmos, H.J.; Møller- Jensen, J.; Andersen, T.E. A Method for Quantification of Epithelium Colonization Capacity by Pathogenic Bacteria. Front. Cell. Infect. Microbiol. 2018, 8, 16. [CrossRef]

49. Onoue, Y.; Takekawa, N.; Nishikino, T.; Kojima, S.; Homma, M. The role of conserved charged residues in the bidirectional rotation of the bacterial flagellar motor. Microbiologyopen 2018, 7, e00587. [CrossRef] 
50. Moor, K.; Diard, M.; Sellin, M.E.; Felmy, B.; Wotzka, S.Y.; Toska, A.; Bakkeren, E.; Arnoldini, M.; Bansept, F.; Co, A.D.; et al. High-avidity IgA protects the intestine by enchaining growing bacteria. Nature 2017, 544, 498-502. [CrossRef]

51. Wang, Q.; Jin, L.; Wang, H.; Tai, S.; Liu, H.; Zhang, D. AWRK6, A Synthetic Cationic Peptide Derived from Antimicrobial Peptide Dybowskin-2CDYa, Inhibits Lipopolysaccharide-Induced Inflammatory Response. Int. J. Mol. Sci. 2018, 19, 600. [CrossRef] [PubMed]

52. Han, B.H.; Lee, Y.J.; Yoon, J.J.; Choi, E.S.; Namgung, S.; Jin, X.J.; Jeong, D.H.; Kang, D.G.; Lee, H.S. Hwangryunhaedoktang exerts anti-inflammation on LPS-induced NO production by suppressing MAPK and NF-kB activation in RAW264.7 macrophages. J. Integr. Med. 2017, 15, 326-336. [CrossRef]

53. Cobos, C.C.; Bansal, P.S.; Navarro, S.; Wilson, D.; Don, L.; Giacomin, P.; Loukas, A.; Daly, N.L. An engineered cyclic peptide alleviates symptoms of inflammation in a murine model of inflammatory bowel disease. J. Biol. Chem. 2017, 292, 10288-10294. [CrossRef] [PubMed]

54. Kiatsurayanon, C.; Ogawa, H.; Niyonsaba, F. The role of host defense peptide human $\beta$-defensins in the maintenance of skin barriers. Curr. Pharm. Des. 2018, 24, 1092-1099. [CrossRef] [PubMed]

55. Zhang, R.Y.; Thapa, P.; Espiritu, M.J.; Menon, V.; Bingham, J.P. From nature to creation: Going around in circles, the art of peptide cyclization. Bioorganic Med. Chem. 2017, 26, 1135. [CrossRef] [PubMed]

56. Morris, A.L.; Macarthur, M.W.; Hutchinson, E.G.; Thornton, J.M. Stereochemical quality of protein structure coordinates. Proteins-Struct. Funct. Bioinform. 2010, 12, 345-364. [CrossRef] [PubMed]

57. Liu, Y.F.; Xia, X.; Xu, L.; Wang, Y.Z. Design of hybrid $\beta$-hairpin peptides with enhanced cell specificity and potent anti-inflammatory activity. Biomaterials 2013, 34, 237-250. [CrossRef] [PubMed]

58. Ma, Q.Q.; Dong, N.; Shan, A.S.; Lv, Y.F.; Li, Y.Z.; Chen, Z.H.; Cheng, B.J.; Li, Z.Y. Biochemical property and membrane-peptide interactions of de novo antimicrobial peptides designed by helix-forming units. Amino Acids 2012, 43, 2527-2536. [CrossRef]

59. Chou, S.; Shao, C.; Wang, J.; Shan, A.; Xu, L.; Dong, N.; Li, Z. Short, multiple-stranded $\beta$-hairpin peptides have antimicrobial potency with high selectivity and salt resistance. Acta Biomater. 2016, 30, 78-93. [CrossRef]

60. Dong, N.; Wang, C.; Zhang, T.; Zhang, L.; Xue, C.; Feng, X.; Bi, C.; Shan, A. Bioactivity and Bactericidal Mechanism of Histidine-Rich $\beta$-Hairpin Peptide Against Gram-Negative Bacteria. Int. J. Mol. Sci. 2019, 20, 3954. [CrossRef]

61. Ouberai, M.; Garch, F.E.; Bussiere, A.; Riou, M.; Alsteens, D.; Lins, L.; Baussanne, I.; Dufrêne, Y.F.; Brasseur, R.; Decout, J.L. The Pseudomonas aeruginosa membranes: A target for a new amphiphilic aminoglycoside derivative? Biochim. Biophys. Acta 2011, 1808, 1716-1727. [CrossRef] [PubMed]

62. Wang, J.; Li, Y.; Wang, X.; Chen, W.; Sun, H.; Wang, J. Lipopolysaccharide induces amyloid formation of antimicrobial peptide HAL-2. Biochim. Biophys. Acta 2014, 1838, 2910-2918. [CrossRef] [PubMed]

63. Yang, Z.; He, S.; Wang, J.; Yang, Y.; Zhang, L.; Li, Y.; Shan, A. Rational Design of Short Peptide Variants by Using Kunitzin-RE, an Amphibian-Derived Bioactivity Peptide, for Acquired Potent Broad-Spectrum Antimicrobial and Improved Therapeutic Potential of Commensalism Coinfection of Pathogens. J. Med. Chem. 2019, 62, 4586-4605. [CrossRef] [PubMed]

64. Lai, Z.; Tan, P.; Zhu, Y.; Shao, C.; Shan, A.; Li, L. Highly Stabilized $\alpha$-Helical Coiled Coils Kill Gram-Negative Bacteria by Multicomplementary Mechanisms under Acidic Condition. ACS Appl. Mater. Interfaces 2019, 11, 22113-22128. [CrossRef] [PubMed]

65. Wang, Z.; Wang, X.; Wang, J. Recent Advances in Antibacterial and Antiendotoxic Peptides or Proteins from Marine Resources. Mar. Drugs 2018, 16, 57. [CrossRef] [PubMed]

66. Rubinchik, E.; Pasetka, C. Assay Systems for Measurement of Anti-inflammatory Activity. Methods Mol. Biol. 2010, 618, 349. [PubMed]

67. Sundar, R.; Francis, S.; Hiradhar, P.K.; Rajesh, N.; Devada, S. Effect of Commiphora mukul in chronic oxazolone induced mouse dermatitis model. Int. J. Vet. Sci. 2016. [CrossRef]

68. Gao, H.; Liu, X.; Sun, W.; Kang, N.; Liu, Y.; Yang, S.; Xu, Q.; Wang, C.; Chen, X. Total tanshinones exhibits anti-inflammatory effects through blocking TLR4 dimerization via the MyD88 pathway. Cell Death Dis. 2017, 8, e3004. [CrossRef]

(C) 2019 by the authors. Licensee MDPI, Basel, Switzerland. This article is an open access article distributed under the terms and conditions of the Creative Commons Attribution (CC BY) license (http://creativecommons.org/licenses/by/4.0/). 